\title{
LRRC8A regulates hypotonicity-induced NLRP3 inflammasome activation
}

Jack P. Green ${ }^{1 * \#}$, Tessa Swanton ${ }^{1 *}$, Lucy V. Morris ${ }^{1}$, Lina Y. El-Sharkawy², James Cook ${ }^{1}$, Shi $\mathrm{Yu}^{1}$, James Beswick${ }^{2}$, Antony Adamson ${ }^{3}$, Neil Humphreys ${ }^{3,4}$, Richard A. Bryce ${ }^{2}$, Sally Freeman $^{2}$, Catherine Lawrence ${ }^{1,5}$, David Brough ${ }^{1,5, \#}$

1Division of Neuroscience and Experimental Psychology, School of Biological Sciences, Faculty of Biology, Medicine and Health, Manchester Academic Health Science Centre, University of Manchester, AV Hill Building, Oxford Road, Manchester, M13 9PT, UK.

2Division of Pharmacy and Optometry, School of Health Sciences, Faculty of Biology, Medicine and Health, Manchester Academic Health Science Centre, The University of Manchester, Stopford Building, Oxford Road, Manchester, M13 9PT, UK.

${ }^{3}$ Genome Editing Unit Core Facility, Faculty of Biology, Medicine and Health, University of Manchester, Manchester, UK.

${ }^{4}$ Present address: EMBL-Rome, Epigenetics and Neurobiology Unit, Adriano BuzzatiTraverso Campus, Via Ramarini 32, 00015 Monterotondo (RM), Italy.

${ }^{5}$ Lydia Becker Institute of Immunology and Inflammation, University of Manchester, Manchester M13 9PT, UK.

* Contributed equally

\# To whom correspondence should be addressed:

David Brough. Tel: +44 (0)161 275 5039; Email: david.brough@manchester.ac.uk Jack Green. Tel +44 (0)161306 0502; Email: jack.green@manchester.ac.uk 


\section{Abstract}

The NLRP3 inflammasome is a multi-molecular protein complex that converts inactive cytokine precursors into active forms of IL-1 $1 \beta$ and IL-18. The NLRP3 inflammasome is frequently associated with the damaging inflammation of non-communicable disease states and is considered a therapeutic target. However, there is much regarding the mechanism of NLRP3 activation that remains unknown. Chloride efflux is suggested as an important step in NLRP3 activation, but the identity of which chloride channels are involved is still unknown. We used chemical, biochemical, and genetic approaches to establish the importance of $\mathrm{Cl}^{-}$ channels in the regulation of NLRP3 activation. Specifically we identify LRRC8A, an essential component of volume-regulated anion channels (VRAC), as a vital regulator of hypotonicityinduced, but not DAMP-induced, NLRP3 inflammasome activation. Although LRRC8A was dispensable for canonical DAMP-dependent NLRP3 activation, this was still sensitive to $\mathrm{Cl}^{-}$ channel inhibitors, suggesting there are additional and specific $\mathrm{Cl}^{-}$sensing and regulating mechanisms controlling NLRP3.

\section{Key Words}

Inflammation, NLRP3 inflammasome, Interleukin-1 $\beta$, Chloride, VRAC, RVD 


\section{Introduction}

Inflammation is an important protective host-response to infection and injury, and yet is also detrimental during non-communicable diseases (1). Inflammasomes are at the heart of inflammatory responses. Inflammasomes are formed by a soluble pattern recognition receptor (PRR), in many cases the adaptor protein ASC (apoptosis-associated speck-like protein containing a CARD), and the protease caspase-1 (2). Inflammasomes form in macrophages in response to a specific stimulus to drive the activation of caspase-1, facilitating the processing of the cytokines pro-interleukin (IL)1 $\beta$ and pro-IL-18 to mature secreted forms, and the cleavage of gasdermin D to cause pyroptotic cell death (2). A number of different inflammasomes have been described, but potentially the inflammasome of greatest interest to non-communicable disease is formed by NLRP3 (NACHT, LRR and PYD domains-containing protein 3) (3). The mechanisms of NLRP3 activation remain poorly understood.

The NLRP3 inflammasome is activated through several routes which have been termed the canonical, non-canonical, and the alternative pathways (3). Activation of the canonical NLRP3 pathway, which has received greatest attention thus far, typically requires two stimuli; an initial priming step with a pathogen associated molecular pattern (PAMP), typically bacterial endotoxin (lipopolysaccharide, LPS), to induce expression of pro-IL-1 $\beta$ and NLRP3, and a second activation step usually involving a damage associated molecular pattern (DAMP), such as adenosine triphosphate (ATP) (4). In 1996, Perregaux and colleagues discovered that hypotonic shock was effective at inducing the release of mature IL-1 $\beta$ when applied to LPS treated human monocytes and suggested the importance of a volume regulated response (5). It was later discovered that hypotonicity induced release of IL-1 $\beta$ via activation of the NLRP3 inflammasome (6), and that this was linked to the regulatory volume decrease (RVD), which is a regulated reduction in cell volume in response to hypo-osmotic-induced cell swelling, and was inhibited by the chloride $\left(\mathrm{Cl}^{-}\right)$channel blocker NPPB (5-nitro-(3- 
phenylpropylamino)benzoic acid) (6). The RVD is regulated by the $\mathrm{Cl}^{-}$channel VRAC (volume regulated anion channel). The molecular composition of the VRAC channel was established to consist of an essential LRRC8A sub-unit in combination with other (B-E) LRRC8 sub-units $(7,8)$. We recently reported that fenamate NSAIDs could inhibit the canonical NLRP3 inflammasome by blocking a $\mathrm{Cl}^{-}$channel, which we suggested could be VRAC (9). We also further characterised the importance of $\mathrm{Cl}^{-}$flux in the regulation of NLRP3, showing that $\mathrm{Cl}^{-}$ efflux facilitated NLRP3-dependent ASC oligomerisation (10). Given the poor specificity of many $\mathrm{Cl}^{-}$channel inhibitors, we set out to systematically determine the importance of VRAC and the RVD to NLRP3 inflammasome activation. Using pharmacological and genetic approaches, we discovered that VRAC exclusively regulated RVD dependent NLRP3 activation in response to hypotonicity, and not NLRP3 activation in response to other canonical stimuli. Thus, we provide genetic evidence for the importance of $\mathrm{Cl}^{-}$in regulating NLRP3 via the VRAC dependence of the hypotonicity response, and suggest the presence of additional $\mathrm{Cl}^{-}$sensing mechanisms regulating NLRP3 in response to DAMPs. 


\section{Results}

Following publication of the cryo-electron microscopy (cryo-EM) structure of VRAC (11) with inhibitor 4-(2-butyl-6,7-dichloro-2-cyclopentyl-indan-1-on-5-yl)oxobutyric acid (DCPIB) (Figure 1A) (12), we were able to investigate the interaction of established VRAC inhibitors with the channel using molecular modelling. DCPIB was first computationally redocked using Molecular Operating Environment (MOE 2015.08, Chemical Computing Group, Canada) into the homohexameric VRAC structure (PDB code 6NZW, resolution $3.2 \AA$ ) (12). The resulting pose produced a reasonable overlay with the cryo-EM conformation of DCPIB, giving a rootmean-square deviation in atomic position of $2.6 \AA$ (Figure 1B, C). DCPIB exhibits an ionic interaction of its carboxylate group with the cationic side-chain of one of the Arg103 residues comprising the electropositive selectivity filter of VRAC (12). Known VRAC inhibitors $(9,13$, 14) possessing carboxylic acid groups (flufenamic acid (FFA), mefenamic acid (MFA) and $N$ ((4-methoxy)-2-naphthyl)-5-nitroanthranilic acid (MONNA), the tetrazole moiety (NS3728) and sulfonic acid groups (4-sulfonic calix(6)arene) were then docked into the DCPIB site of VRAC. The most favourably bound poses of these ligands were similarly found to block the pore in a cork-in-bottle manner (12) at the selectivity filter; the ligands' ionized acidic groups formed strong electrostatic interactions with Arg103 (Figure 1D-H). Tamoxifen, a basic inhibitor of VRAC was also docked into the cryo-EM structure (Figure 1I). Accordingly, tamoxifen docked with its cationic tertiary amino group remote to the Arg103 side-chains (Figures 11 and Supplementary Figure 1); these side-chains instead formed cation- $\pi$ interactions with the phenyl group of tamoxifen (Figure 1I). The interaction of the tamoxifen pose was computed as having a calculated ligand-binding affinity of $-6.5 \mathrm{kcal} \mathrm{mol}^{-1}$ via the molecular mechanics/generalized Born volume integration (MM/GBVI) method (15, 16). The binding energies of the anionic ligands were also predicted as favourable, ranging from -5.1 (DCPIB) to $-5.8 \mathrm{kcal} \mathrm{mol}^{-1}$ (MONNA). This range excludes the larger 4-sulfonic calix(6)arene (calixarene), which gave a binding energy of $-9.9 \mathrm{kcal} \mathrm{mol}^{-1}$; we note that the GBVI implicit solvent model may be underestimating the high desolvation cost of this polyanionic ligand and 
therefore overestimating the magnitude of the corresponding binding energy of this compound.

We then tested the ability of six of the compounds described in Figure 1 (DCPIB, calixarene (Calix), tamoxifen, FFA, MONNA, NS3728) to inhibit hypotonicity-induced VRAC-dependent $\mathrm{Cl}^{-}$flux using the iodide $\left(\mathrm{I}^{-}\right)$quenching of halide-sensitive YFP H148Q/I152L (17) in live HeLa cells (Figure 2A). In this model, l- enters the cell through open $\mathrm{Cl}^{-}$channels to induce quenching of a mutant EYFP. In response to hypotonic shock to induce VRAC opening, YFP fluorescence was immediately quenched, which was significantly inhibited by tamoxifen (10 $\mu \mathrm{M})$, MONNA $(50 \mu \mathrm{M})$, DCPIB $(10 \mu \mathrm{M})$, FFA $(100 \mu \mathrm{M})$ and NS3728 $(10 \mu \mathrm{M})$, but not calixarene $(100 \mu \mathrm{M})$ (Figure 2A, B). VRAC also regulates RVD in response to cell swelling $(7,8)$. We measured the RVD by measuring the change in cellular fluorescence in calcein-loaded primary mouse bone marrow-derived macrophages (BMDMs) in response to hypotonicity. Hypotonicity caused a rapid increase in cell volume which declined over time, characteristic of an RVD response (Figure 2C). Similar to the quenching assay, RVD was also significantly inhibited in the presence of tamoxifen, MONNA, DCPIB, FFA and NS3728, but not calixarene (Figure 2C, D). These data suggest that all the molecules in our panel, except calixarene, are bona-fide VRAC inhibitors at the concentrations tested.

We tested whether the panel of VRAC inhibitors characterised above could block NLRP3 inflammasome activation and release of IL-1 $\beta$ in response to DAMP stimulation. Primary BMDMs were primed with LPS $\left(1 \mu \mathrm{g} \mathrm{mL}^{-1}, 4 \mathrm{~h}\right)$, before activation of NLRP3 by ATP ( $5 \mathrm{mM}, 2$ h). Inhibitors were given at the same dose they inhibited VRAC above in HeLa cells 15 minutes before the addition of ATP and were then present for the duration of the experiment. Of the panel of verified VRAC inhibitors, only MONNA, FFA and NS3728 consistently inhibited ATPinduced IL-1 $\beta$ release (Figure 3A). At the dose used in this assay, DCPIB did not consistently 
inhibit ATP-induced IL-1 $\beta$ release (Figure 3A), but at higher concentrations did inhibit NLRP3 activation (Supplementary Figure 2). Likewise, pyroptosis, as measured by LDH release, was significantly reduced by MONNA and FFA, and was unaffected by tamoxifen or calixarene (Figure $3 \mathrm{~B}$ ). The inhibitors that blocked ATP-induced IL-1 $\beta$ release also inhibited ASC oligomerisation, caspase-1 activation, and gasdermin D cleavage (Figure $3 C$ ). These data show that some very effective VRAC inhibitors failed to inhibit activation of the NLRP3 inflammasome and release of IL-1 $\beta$, suggesting that VRAC may not be the molecular target of these molecules inhibiting the inflammasome.

ATP-induced NLRP3 activation is dependent upon $\mathrm{K}^{+}$efflux, whereas NLRP3 activation by treatment with the imidazoquinoline compound imiquimod is $\mathrm{K}^{+}$efflux-independent (18). We therefore sought to test if VRAC inhibitors that were effective at blocking ATP-induced inflammasome activation were specific to $\mathrm{K}^{+}$efflux sensitive mechanisms. FFA (100 $\left.\mu \mathrm{M}\right)$ and NS3728 $(10 \mu \mathrm{M})$ were effective at blocking IL-1 $\beta$ release after treatment with the $\mathrm{K}^{+}$ionophore nigericin (10 $\mu \mathrm{M}, 2 \mathrm{~h})$ (Figure 3D), but were unable to block imiquimod (75 $\mu \mathrm{M}, 2 \mathrm{~h}$ )-induced IL-1 $\beta$ release (Figure 3E). Similarly, ASC oligomerisation, caspase-1 activation and gasdermin D cleavage induced by nigericin were sensitive to FFA and NS3728 pre-treatment (Figure 3F). However, ASC oligomerisation, caspase-1 activation and gasdermin D cleavage induced by imiquimod were not affected by FFA and NS3728 pre-treatment (Figure 3F). Increased extracellular $\mathrm{KCl}(25 \mathrm{mM})$ was sufficient to block nigericin-induced activation, but not imiquimod, demonstrating the $\mathrm{K}^{+}$dependency of nigericin (Figure 3F). These data suggest that these $\mathrm{Cl}^{-}$channel inhibiting compounds exclusively target the $\mathrm{K}^{+}$-dependent canonical pathway of NLRP3 activation.

Many $\mathrm{Cl}^{-}$channel inhibiting drugs are known to inhibit multiple $\mathrm{Cl}^{-}$channels, and we established that very effective VRAC inhibitors (tamoxifen and DCPIB) had negligible effect 
on NLRP3 activation at VRAC inhibiting concentrations. Thus, to conclusively determine the role of VRAC in NLRP3 inflammasome activation we generated a macrophage specific LRRC8A knockout (KO) mouse using CRISPR/Cas9 (Figure 4A). The generation of a macrophage specific LRRC8A KO was required as whole animal LRRC8A KO mice do not survive beyond four weeks and have retarded growth (19). Lrrc8 $a^{f / / t+1}$ mice were bred with mice constitutively expressing Cre under the $C \times 3 \operatorname{cr} 1$ promoter, as previously shown to be expressed in monocyte and macrophage populations (20). This generated mice with the genotype $\operatorname{Lrc8} a^{f / f t l}: C \times 3 c r 1^{c r e}(\mathrm{KO})$ with littermates $\operatorname{Lrc8} a^{f / f t l}: C \times 3 c r 1^{W T}(\mathrm{WT})$. Cell lysates were prepared from BMDMs and peritoneal macrophages isolated from WT and KO mice and were western blotted for LRRC8A confirming that Lrrc8a KO cells were knocked out for LRRC8A (Figure 4B). Functional loss of LRRC8A was confirmed using the calcein RVD assay described above. BMDMs were subjected to a hypotonic shock and changes in calcein fluorescence measured over time. In WT cells there was a characteristic RVD (Figure 4C). However, in Lrrc8a KO cells there was complete loss of the RVD response (Figure $4 \mathrm{C}, \mathrm{D}$ ). The absence of RVD was also strikingly evident by observation of the cells by phase contrast microscopy (Figure 4E, Supplementary videos 1, 2). These data confirm functional KO of the VRAC channel in macrophages.

We next used the Lrrc8a KO macrophages to test the hypothesis that VRAC and the RVD were important for NLRP3 inflammasome activation and IL-1 $\beta$ release in response to DAMP stimulation. WT BMDMs and Lrrc8a KO BMDMs were primed with LPS ( $\left.1 \mu \mathrm{g} \mathrm{mL}^{-1}, 4 \mathrm{~h}\right)$ and then treated with the NLRP3 inflammasome activators ATP $(5 \mathrm{mM}, 2 \mathrm{~h})$, nigericin $(10 \mu \mathrm{M}, 2$ h), silica (300 $\left.\mu \mathrm{g} \mathrm{mL}^{-1}, 2 \mathrm{~h}\right)$, or imiquimod (75 $\left.\mu \mathrm{M}, 2 \mathrm{~h}\right)$. Knocking out LRRC8A had no effect on the release of IL-1 $\beta$ (Figure $5 \mathrm{~A}$ ) or cell death (Figure 5B). We then used western blotting to determine ASC oligomerisation and caspase-1 activation. In response to the NLRP3 inflammasome activators nigericin, ATP, and imiquimod, there was no effect of LRRC8A KO on ASC oligomerisation or caspase-1 activation (Figure $5 \mathrm{C}$ ). Furthermore, IL-1 $\beta$ release in 
response to ATP or nigericin was still inhibited by the VRAC inhibitors flufenamic acid (FFA, $100 \mu \mathrm{M})$, and NS3728 $(10 \mu \mathrm{M})$ in the Lrrc8a KO BMDMs, confirming that these inhibitors are inhibiting NLRP3 inflammasome activation by a VRAC-independent mechanism (Figure 5D). Flufenamic acid and NS3728 also inhibited ASC oligomerisation and caspase-1 activation as determined by western blot in the Lrrc8a KO BMDMs to the same extent as in the WT (Figure $5 \mathrm{E})$. We then used a murine peritonitis model described previously (9) to investigate the role of LRRC8A in vivo. First, we tested if the VRAC inhibitor NS3728 was effective at blocking NLRP3 in vivo. Wild type C57BL6/J mice were injected intraperitoneally with NS3728 (50 mg $\left.\mathrm{kg}^{-1}\right)$, the NLRP3 inhibitor MCC950 (50 mg kg-1), or vehicle control, at the same time as LPS ( $1 \mu \mathrm{g}, 4 \mathrm{~h})$. NLRP3 was then further activated by intraperitoneal injection of ATP (100 mM, $500 \mu \mathrm{L}, 15 \mathrm{~min}$ ) and IL-1 $\beta$ release was measured by ELISA of the peritoneal lavage (Figure 5F) and plasma (Figure 5G). Addition of ATP induced a significant increase in the release of IL-1 $\beta$ into peritoneal lavage and this was inhibited by MCC950 and NS3728, indicating an NLRP3-dependent response. IL-6 levels were unaltered in both peritoneal lavage and plasma by addition of NS3728 (Supplementary Figure 3A, B). These data show that NS3728 was able to inhibit NLRP3 in vivo. To determine the role of VRAC in this model, we repeated this experiment in our macrophage Lrrc8a KO mice and their littermate controls. Macrophage Lrrc8a KO mice exhibited normal proportions of myeloid cells in the peritoneum as assessed by flow cytometry (Supplementary Figure 3C-G). Loss of macrophage LRRC8A had no effect on the IL-1 $\beta$ levels in the peritoneal lavage in response to LPS and ATP (Figure $5 \mathrm{H}$ ), or in the plasma (Figure 5I). Moreover, similar to our in vitro findings, NS3728 was still effective at inhibiting this response in the absence of LRRC8A (Figure $5 \mathrm{H}, \mathrm{I})$. These data suggested that VRAC was dispensable for NLRP3 activation by DAMP stimulation, and that the VRAC inhibitors are effective at inhibiting NLRP3 in the absence of VRAC, suggesting the presence of another target. 
RVD in response to hypo-osmotic-induced cell swelling is documented as an inducer of NLRP3 inflammasome activation and IL-1 $1 \beta$ release $(5,6)$. Since Lrrc8a KO BMDMs could no longer control their volume in response to hypotonic shock, we tested whether NLRP3 inflammasome activation by hypotonicity was altered. LPS-primed $\left(1 \mu \mathrm{g} \mathrm{mL} \mathrm{L}^{-1}, 4 \mathrm{~h}\right)$ BMDMs were incubated in a hypotonic solution ( $4 \mathrm{~h}$ ) which caused IL-1 $\beta$ and LDH release from WT cells, and which was significantly inhibited in Lrrc8a KO BMDMs (Figure 6A,B). There was no difference in IL-1 $\beta$ release or cell death between ATP-stimulated WT and KO BMDMs (Figure $6 \mathrm{~A}, \mathrm{~B})$. Caspase-1 cleavage and IL-1 $\beta$ processing induced by hypotonicity were also completely inhibited in the absence of LRRC8A (Figure 6C), indicating the response was completely dependent on both NLRP3 and VRAC. Moreover, hypotonicity-induced ASC oligomerisation was also dependent on VRAC (Figure 6D). These data show that in response to hypo-osmotic stress, VRAC was essential for NLRP3 inflammasome activation. 


\section{Discussion}

Pharmacological and biochemical evidence supporting an important role of $\mathrm{Cl}^{-}$ions in the activation of the NLRP3 inflammasome has been provided by various studies over the years $(5,6,9,10,21)$, although conclusive genetic evidence has been lacking. The promiscuous nature of many $\mathrm{Cl}^{-}$channel inhibiting drugs, and an unresolved molecular identity of major $\mathrm{Cl}^{-}$ channels, have prevented the emergence of conclusive genetic proof. However, the discovery that the $\mathrm{Cl}^{-}$channel regulating the RVD (VRAC) was composed of LRRC8 sub-units, and that LRRC8A was essential for channel activity, offered us the opportunity to investigate the direct importance of VRAC in the regulation of NLRP3. Hypotonicity induces cell swelling which is corrected by the VRAC-dependent RVD $(7,8)$. The RVD was previously linked to NLRP3 activation (6). Thus by knocking out LRRC8A, and thus VRAC, we would discover that VRAC was essential for RVD-induced NLRP3 inflammasome activation, providing strong evidence for the direct requirement of a $\mathrm{Cl}^{-}$channel in NLRP3 inflammasome activation.

However VRAC was only essential for RVD induced NLRP3 activation and was not involved in the NLRP3 response to DAMP stimulation. The fact that our VRAC channel inhibiting drugs block DAMP-induced NLRP3 activation suggests that additional $\mathrm{Cl}^{-}$channels are involved in coordinating NLRP3 responses to other stimuli. Chloride intracellular channel proteins (CLICs $1-6)$ form anion channels and regulate a variety of cellular processes $(22,23)$. Localisation of CLIC1 and 4 to membrane fractions in macrophages is increased by LPS stimulation, and RNAi knockdown of both CLIC1 and 4 impaired LPS and ATP-induced IL-1 $\beta$ release from macrophages (24). In addition to CLICs 1 and 4, CLIC5 is also implicated in NLRP3-dependent IL-1 $\beta$ release (25). Knockdown of CLICs 1, 4, and 5 inhibits NLRP3 inflammasome activation in response to the soluble agonists ATP and nigericin, and also the particulate DAMP monosodium urate crystals (25). Thus, it appears that multiple $\mathrm{Cl}^{-}$channels encode diverse 
signals arising from DAMP stimulation, or from altered cellular homeostasis, to trigger NLRP3 inflammasome activation.

Inhibiting the NLRP3 inflammasome has become an area of intense research interest due to the multiple indications of its role in disease (3). The inhibitor MCC950 is now thought to bind directly to NLRP3 to cause inhibition $(26,27)$, although it has also been reported to inhibit $\mathrm{Cl}^{-}$ flux from macrophages treated with nigericin (28), and was found to bind directly to CLIC1 (29), so it is possible that some of its inhibitory activity may be attributable to an effect on $\mathrm{Cl}^{-}$. We found that $\mathrm{Cl}^{-}$channel inhibition blocked IL-1 $\beta$ release in a NLRP3-dependent model of peritonitis, and previously reported protective effects of the fenamate NSAIDs in rodent models of Alzheimer's disease that we attributed to an effect on $\mathrm{Cl}^{-}$channel inhibition (9). Thus, it is possible that targeting $\mathrm{Cl}^{-}$channels offers an additional route to inhibit NLRP3-dependent inflammation in disease.

In summary, we have reported that hypotonicity induced NLRP3 inflammasome activation depends exclusively on the $\mathrm{Cl}^{-}$channel VRAC, and that different $\mathrm{Cl}^{-}$sensing and regulating systems coordinate the activation of NLRP3 in response to DAMPs. This opens the possibility of discrete $\mathrm{Cl}^{-}$regulating mechanisms conferring selectivity and information about the nature of the NLRP3 activating stimulus. Thus, this investigation has opened the door to further studies on $\mathrm{Cl}^{-}$regulation of NLRP3 and identified the possibility of selective therapeutic intervention strategies informed by the nature of the disease or DAMP stimulus, potentially minimising complications of immunosuppression caused by a blanket NLRP3 inhibition. 


\section{Methods}

\section{Computational chemistry}

Docking of ligands to VRAC employed the recently solved cryo-EM structure of VRAC (PDB: 6NZW, resolution $3.2 \AA$ ) (12). Tautomeric and ionization states of VRAC amino acid residues at pH 7.4 were assigned using MOE (MOE 2015.08, Chemical Computing Group, Canada). Similarly, ligands were modelled in their ionized forms according to physiological conditions. Docking was performed with the Triangle Matcher placement method of MOE using the London dG scoring function (MOE 2015.08, Chemical Computing Group, Canada). The pocket into which the VRAC inhibitors were docked was that occupied by the (S)-isomer of DCPIB in the cryo-EM structure of VRAC. Rescoring of poses used the molecular mechanics (MM)/generalized Born/volume integral (GBVI) potential (15).

\section{Antibodies and Reagents}

Specific antibodies were used targeting: IL-1ß (AF-401-NA, R\&D), caspase-1 (ab179515, abcam), gasdermin D (ab20945, abcam), ASC (67824, CST), LRRC8A (8H9, Santa Cruz) and $\beta$-actin (A3854, Sigma).

Lipopolysaccharide (LPS, in vitro: Escherichia coli 026:B6, L2654, in vivo: Escherichia coli 0127:B8, L3880), adenosine triphosphate (ATP, A2383), nigericin (N7143), tamoxifen (T5648), flufenamic acid (FFA, F9005), CP-456773 (MCC950, PZ0280), sodium iodide (Nal, 409286) were purchased from Sigma. Disuccinimidyl suberate (DSS, 21555), calcein AM (C1430) and 4-sulfonic calix[6]arene (10494735) were purchased from Thermo Fisher. 4-[(2Butyl-6,7-dichloro-2-cyclopentyl-2,3-dihydro-1-oxo-1H-inden-5-yl)oxy]butanoic acid (DCPIB, 1540) was from Tocris. NS3728 and NBC19 were made at the University of Manchester. 


\section{Cell Culture}

Primary bone marrow derived macrophages (BMDMs) and peritoneal macrophages were isolated from male and female wild-type C57BL6/J mice. Bone marrow was harvested from both femurs, red blood cells were lysed and resulting marrow cells were cultured in $70 \%$ DMEM (10\% v/v FBS, $100 \mathrm{U} / \mathrm{mL}$ penicillin, $100 \mu \mathrm{g} / \mathrm{mL}$ streptomycin) supplemented with $30 \%$ L929 mouse fibroblast-conditioned media for 6-7 days. BMDMs were seeded out the day before at a density of $1 \times 10^{6} \mathrm{~mL}^{-1}$ in DMEM (10\% v/v FBS, $100 \mathrm{U} \mathrm{mL}^{-1}$ penicillin, $100 \mathrm{\mu g} \mathrm{mL}^{-1}$ streptomycin). Peritoneal macrophages were isolated by peritoneal lavage and seeded out overnight at a density of $1 \times 10^{6} \mathrm{~mL}^{-1}$ in DMEM $\left(10 \% \mathrm{v} / \mathrm{v} \mathrm{FBS,} 100 \mathrm{U} \mathrm{mL}^{-1}\right.$ penicillin, $100 \mu \mathrm{gL}^{-}$

${ }^{1}$ streptomycin). HeLa cells were seeded out at $0.1 \times 10^{6} \mathrm{~mL}^{-1}$ in DMEM $(10 \% \mathrm{v} / \mathrm{v}$ FBS, $100 \mathrm{U}$ $\mathrm{mL}^{-1}$ penicillin, $100 \mu \mathrm{gL}^{-1}$ streptomycin).

\section{Inflammasome activation assays}

Primary BMDMs were primed with LPS $\left(1 \mu \mathrm{g} \mathrm{mL} \mathrm{L}^{-1}, 4 \mathrm{~h}\right)$ in DMEM $\left(10 \% \mathrm{v} / \mathrm{v}\right.$ FBS, $100 \mathrm{U} \mathrm{mL}^{-1}$ penicillin, $100 \mu \mathrm{g} \mathrm{mL}^{-1}$ streptomycin). After priming, the media was replaced with serum-free DMEM, or when specified an isotonic buffer (132 mM NaCl, $2.6 \mathrm{mM} \mathrm{KCl}, 1.4 \mathrm{mM} \mathrm{KH}_{2} \mathrm{PO}_{4}, 0.5$ $\mathrm{mM} \mathrm{MgCl} 2,0.9 \mathrm{mM} \mathrm{CaCl}_{2}, 20 \mathrm{mM}$ HEPES, $5 \mathrm{mM} \mathrm{NaHCO}_{3}, 5 \mathrm{mM}$ Glucose, pH 7.3, 340 $\mathrm{mOsm} / \mathrm{kg}$ ) or hypotonic buffer $\left(27 \mathrm{mM} \mathrm{NaCl}, 0.54 \mathrm{mM} \mathrm{KCl}, 0.3 \mathrm{mM} \mathrm{KH}_{2} \mathrm{PO}_{4}, 0.5 \mathrm{mM} \mathrm{MgCl}\right.$, $0.9 \mathrm{mM} \mathrm{CaCl}_{2}, 20 \mathrm{mM} \mathrm{HEPES} 5 \mathrm{mM} \mathrm{NaHCO}_{3}, 5 \mathrm{mM}$ Glucose, $\mathrm{pH}$ 7.3, $117 \mathrm{mOsm} \mathrm{kg}^{-1}$ ). When used, VRAC inhibitors were added 15 minutes before stimulation of the NLRP3 inflammasome.

For analysis of IL-1 $1 \beta$ release and pyroptosis, cell supernatants were collected. IL $-1 \beta$ release was determined by ELISA (DuoSet, R\&D Systems) according to the manufacturer's instructions. Cell death was assessed by lactate dehydrogenase (LDH) release using CytoTox 96 nonradioactive cytotoxicity assay (Promega) according to manufacturer's instructions. For 
western blotting, total cell lysates were made by directly adding protease inhibitor cocktail and Triton $\mathrm{x}-100(1 \% \mathrm{v} / \mathrm{v})$ to each well containing cells and supernatant.

\section{ASC oligomerisation assay}

$1 \times 10^{6}$ primary BMDMs were seeded out overnight into 12-well plates. After LPS priming (1 $\mu \mathrm{g} \mathrm{mL} \mathrm{m}^{-1}, 4 \mathrm{~h}$ ), cells were incubated in either serum-free DMEM, an isotonic or a hypotonic buffer (as described above) and stimulated as described. BMDMs were lysed directly in-well by addition of protease inhibitor cocktail and Triton $x-100(1 \% \mathrm{v} / \mathrm{v})$ and lysed on ice. Total cell lysates were then spun at $6800 \mathrm{xg}$ for $20 \mathrm{~min}$ at $4^{\circ} \mathrm{C}$ to separate the lysate into Triton $\mathrm{x}-100$ soluble and insoluble fractions. The Triton $x-100$ insoluble fraction (pellet) was then chemically crosslinked by addition of disuccinimidyl suberate (DSS, $2 \mathrm{mM}, 30 \mathrm{~min}, \mathrm{RT}$ ) in PBS. Following crosslinking, the insoluble fraction was spun at $6800 \mathrm{xg}$ for $20 \mathrm{~min}$ and the resulting pellet was resuspended and boiled in $40 \mu \mathrm{L} 1 \mathrm{X}$ Laemlli buffer. The Triton $\mathrm{x}-100$ soluble fraction was concentrated by trichloroacetic acid (TCA) precipitation. Triton $\mathrm{x}-100$ soluble lysate was mixed $1: 1$ with TCA $(20 \% \mathrm{w} / \mathrm{v})$ and spun at $14000 \mathrm{xg}$ for $10 \mathrm{~min}$ at $4^{\circ} \mathrm{C}$. The pellet was then washed in acetone, spun at $14000 \mathrm{xg}$ for $10 \mathrm{~min}$ at $4^{\circ} \mathrm{C}$, and resuspended in $2 \mathrm{X}$ Laemlli buffer.

\section{Regulatory volume decrease (RVD) assay}

$5 \times 10^{4}$ BMDMs were seeded out into black walled 96-well plates overnight. Cells were loaded with calcein $\left(10 \mu \mathrm{M}, 1 \mathrm{~h}, 37^{\circ} \mathrm{C}\right)$ in an isotonic buffer $(132 \mathrm{mM} \mathrm{NaCl}, 2.6 \mathrm{mM} \mathrm{KCl}, 1.4 \mathrm{mM}$ $\mathrm{KH}_{2} \mathrm{PO}_{4}, 0.5 \mathrm{mM} \mathrm{MgCl}_{2}, 0.9 \mathrm{mM} \mathrm{CaCl}, 20 \mathrm{mM}$ HEPES, $5 \mathrm{mM} \mathrm{NaHCO}$, $5 \mathrm{mM}$ Glucose, $\mathrm{pH}$ 7.3, $340 \mathrm{mOsm} \mathrm{kg}^{-1}$ ). Following loading, BMDMs were washed three times with isotonic buffer before incubation with VRAC inhibitors or vehicle control at indicated concentrations for $5 \mathrm{~min}$. GFP fluorescence was then imaged for a further 5 min before hypotonic shock was induced by a five-fold dilution with a hypotonic buffer $\left(0.9 \mathrm{mM} \mathrm{CaCl}_{2}, 20 \mathrm{mM} \mathrm{HEPES,} 5 \mathrm{mM} \mathrm{NaHCO}_{3}\right.$, 
$5 \mathrm{mM}$ Glucose, $\mathrm{pH}$ 7.3), resulting in a final osmolarity of $117 \mathrm{mOsm} \mathrm{kg}^{-1}$. GFP fluorescence was measured on an Eclipse Ti inverted microscope (Nikon) and analysed using Image $\mathrm{J}$ software. Point visiting was used to allow multiple positions to be imaged within the same timecourse and cells were maintained at $37^{\circ} \mathrm{C}$ and $5 \% \mathrm{CO}_{2}$. For experiments with VRAC inhibitors, combined treatment with hypotonicity and VRAC inhibitors resulted in some cells undergoing lytic cell death over the course of the experiment and loss of calcein fluorescence. Therefore, GFP fluorescence was used to identify the area of living cells.

\section{lodide YFP quenching assay}

HeLa cells were seeded at a density of $0.1 \times 10^{6} \mathrm{ml}^{-1}$ in black-walled, clear bottom 96 -well plates (Greiner). Transient transfection with the halide-sensitive YFP mutant pcDNA3.1 EYFP H148Q/152L, a gift from Peter Haggie (Addgene plasmid \# 25872), was performed using Lipofectamine 3000 (Thermo Fisher). 18-24 h post-transfection, HeLa cells were washed twice with isotonic buffer (140 mM NaCl, $5 \mathrm{mM} \mathrm{KCl,} 20 \mathrm{mM} \mathrm{HEPES,} \mathrm{pH}$ 7.4, $310 \mathrm{mOsm} \mathrm{kg}^{-1}$ ) before 5 min incubation in $50 \mu \mathrm{L}$ isotonic buffer containing either drug at indicated concentrations, or vehicle. $50 \mu$ isotonic or hypotonic $(5 \mathrm{mM} \mathrm{KCl}, 20 \mathrm{mM}$ HEPES, $90 \mathrm{mM}$ mannitol, $\mathrm{pH}$ 7.4, 120 mOsm $\mathrm{kg}^{-1}$ ) buffer containing either drug or vehicle was then added and cells were incubated for a further $5 \mathrm{~min}$. $\mathrm{Nal}(200 \mathrm{mM}, 25 \mu \mathrm{L})$ was then added directly to the well, and fluorescence readings were take every 2 seconds using the FlexStation3 plate reader.

\section{Generation of $L r r c 8 a^{f / f l}$ mice}

We used CRISPR-Cas9 to generate the floxed LRRC8A allele on C57BL/6J background. LRRC8A is a 4 exon gene spanning $26 \mathrm{~kb}$ on mouse chromosome 2 . Only 2 of these exons contain coding sequence, with exon 3 harbouring $>85 \%$ of the coding sequence and possessing large introns, and thus an ideal candidate for floxing. We initially attempted the 2sgRNA, 2-oligo approach described previously (30), but failed to obtain mice with both loxP 
integrated on the same allele (31). Instead, a colony from a single founder with the 5' LoxP integrated was established, bred to homozygosity, and used as a background to integrate the second 3' loxP. For both steps, we used the Sanger WTSI website (http://www.sanger.ac.uk/htgt/wge/, (32)) to design sgRNA that adhered to our criteria for off target predictions (guides with mismatch $(\mathrm{MM})$ of 0,1 or 2 for elsewhere in the genome were discounted, and MM3 were tolerated if predicted off targets were not exonic). sgRNA sequences were purchased as crRNA oligos, which were annealed with tracrRNA (both oligos supplied IDT; Coralville, USA) in sterile, RNase free injection buffer (Tris $\mathrm{HCl} 1 \mathrm{mM}, \mathrm{pH} 7.5$, EDTA $0.1 \mathrm{mM}$ ) by combining $2.5 \mu \mathrm{g}$ crRNA with $5 \mu \mathrm{g}$ tracrRNA and heating to $95^{\circ} \mathrm{C}$, which was allowed to slowly cool to room temperature.

For 5' targeting the sgRNA GTCTAGTTAGGGACTCCTGG-GGG was used, with the ssODN repair template

tccttgacttgctgtttaccgctctcttccccacaccacagttatccacaggaagttacccataacctccctcgtg acccctaccccc aATAACTTCGTATAGCATACATTATACGAAGTTATGGTACCggagtccctaactagacctgctgtctctc catagccctgtctacacct-3', where capitals indicate the LoxP sequence with a Kpnl site, and lower case the homology arms. For embryo microinjection the annealed sgRNA was complexed with Cas9 protein (New England Biolabs) at room temperature for $10 \mathrm{~min}$, before addition of ssODN (IDT) donor (final concentrations; sgRNA $20 \mathrm{ng} \mu \mathrm{L}^{-1}$, Cas9 protein $20 \mathrm{ng} \mathrm{LL}^{-1}$, ssODN $50 \mathrm{ng}$ $\mu \mathrm{L}^{-1}$ ). CRISPR reagents were directly microinjected into C57BL6/J (Envigo) zygote pronuclei using standard protocols (33). Zygotes were cultured overnight and the resulting 2 cell embryos surgically implanted into the oviduct of day 0.5 post-coitum pseudopregnant mice. Potential founder mice were identified by extraction of genomic DNA from ear clips, followed by PCR using primers that flank the homology arms and sgRNA sites (Geno F1 tcagatggcgaaccagaagtc and Geno R1 tacaatgtagtcaggtgtgacg). WT sequences produced a 833bp band, and loxP knock in $873 \mathrm{bp}$, which is also susceptible to Kpnl digest. Pups with a larger band were reserved, the band isolated and amplified using high fidelity Phusion polymerase (NEB), gel extracted and subcloned into pCRblunt (Invitrogen). Colonies were 
mini-prepped and Sanger sequenced with M13 Forward and Reverse primers, and aligned to predicted knock-in sequence. Positive pups were bred with a WT C57BL6/J to confirm germline transmission and a colony established. To integrate the 3' LoxP we used sgRNA ACTACCCCATTACCTCTTGG-TGG with the ssODN repair template 5'gagggccaaaactgtggaaagcaacacccttgaagtgtaggtggcccctgtgcaccagctctgtgtgtgactgcaaagccccc accaagaATAACTTCGTATAGCATACATTATACGAAGTTATGGTACCggtaatggggtagttagacgg gctgagggcagagcacttgtgtggctt-3'. Again, capitals indicate the LoxP sequence with a Kpnl site, and lower case the homology arms.

For this second round of targeting we generated embryos from the LRRC8A-5'fl colony by IVF using homozygous LRRC8A-5'fl mice, and used electroporation (Nepa21 electroporator, Sonidel) to deliver the sgRNA:Cas9 RNP complex and ssODN to the embryos, AltR crRNA:tracrRNA:Cas9 complex (200 ng $\mu \mathrm{L}^{-1} ; 200 \mathrm{ng} \mu \mathrm{L}^{-1} ; 200 \mathrm{ng} \mu \mathrm{L}^{-1}$ respectively) and ssDNA HDR template (500 $\mathrm{ng} \mathrm{LL}^{-1}$ ) (34). Zygotes were cultured overnight and the resulting 2 cell embryos surgically implanted into the oviduct of day 0.5 post-coitum pseudopregnant mice. Potential founder mice were identified by extraction of genomic DNA from ear clips, followed by PCR using primers that flank the homology arms and sgRNA sites (Geno F2 atccccactgcttttctgga and Geno R2 ccactcaagagccagcaatg). WT sequences produced a $371 \mathrm{bp}$ band, and loxP knock in $411 \mathrm{bp}$, which is also susceptible to Kpnl digest. As before, Pups with a larger band were reserved, the band isolated and amplified using high fidelity Phusion polymerase (NEB), gel extracted and subcloned into pCRblunt (Invitrogen). Colonies were mini-prepped and Sanger sequenced with M13 Forward and Reverse primers, and aligned to predicted knock-in sequence. Positive pups were bred with a WT C57BL6/J to confirm germline transmission and a colony established $\left(\operatorname{Lrc8} a^{f / / f t}\right) . \quad L r r c 8 a^{f / / f l}$ mice were bred with Cx3cr $1^{\text {cre }}$ mice (as previously described (20)) to generate $\operatorname{Lrc} 8 a^{f / / f l} C \times 3 c r 1^{\text {cre } /+}$ mice, which specifically induce removal of LRRC8A in cells expressing CX3CR1 (LrrC8a KO). CX3CR1cre mice were obtained from a breeding colony at the University of Manchester managed by 
John Grainger. Experiments using Lrrc8a KO cells were compared to wild-type littermate controls $\left(\operatorname{Lrrc8a}^{\mathrm{fl} / \mathrm{fl}} \mathrm{C} \times 3 \mathrm{Cr} 1^{+/+}\right)$.

\section{In vivo peritoneal inflammation model}

All procedures were performed with appropriate personal and project licenses in place, in accordance with the Home Office (Animals) Scientific Procedures Act (1986), and approved by the Home Office and the local Animal Ethical Review Group, University of Manchester. 810 week-old male wild type (WT) C57BL/6J mice (Charles River) were used to test efficacy of NS3728 and MCC950. Mice were treated intraperitoneally with LPS $\left(2 \mu \mathrm{g} \mathrm{mL}^{-1}, 500 \mu \mathrm{L}\right)$ and either a vehicle control (5\% DMSO (v/v), 5\% Cremophor (v/v), 5\% ethanol (v/v) in PBS), NS3728 $\left(50 \mathrm{mg} \mathrm{kg}^{-1}\right)$ or MCC950 $\left(50 \mathrm{mg} \mathrm{kg}^{-1}\right)$ for $4 \mathrm{~h}$. Mice were then anesthetised with isofluorane (induced at $3 \%$ in $33 \% \mathrm{O}_{2}, 67 \% \mathrm{NO}_{2}$, maintained at $1-2 \%$ ) before injection with a vehicle control, NS3728 or MCC950 as before and ATP $(0.5 \mathrm{~mL}, 100 \mathrm{mM}$ in PBS, pH 7.4) or PBS for 15 min. The peritoneum was then lavaged with RPMI 1640 (3 mL) and blood was collected via cardiac puncture. For experiments using Lrrc8a knockout (KO) mice, 8-10 weekold male and female Lrrc8a KO and WT littermate controls were used and treated as described above. Plasma and lavage fluid was used for cytokine analysis. BCA analysis was performed on the peritoneal lavage fluid to normalise cytokine release to total protein level. Murine studies were performed with the researcher blinded to genotype and treatment for the duration of the experiment.

\section{Flow cytometry}

8-10 week-old male and female Lrrc8a KO and WT littermate controls were anesthetised with isofluorane (induced at $3 \%$ in $33 \% \mathrm{O}_{2}, 67 \% \mathrm{NO}_{2}$, maintained at $1-2 \%$ ) and the peritoneal cavity was lavaged with $6 \mathrm{~mL}$ RPMI $\left(3 \% \mathrm{v} / \mathrm{v}\right.$ FBS, $100 \mathrm{U} \mathrm{mL}^{-1}$ penicillin, $100 \mu \mathrm{g} \mathrm{mL}^{-1}$ 
streptomycin, 1 mM EDTA) before sacrifice. Red blood cells were lysed using Pharmlyse (BD Biosciences) in $\mathrm{H}_{2} \mathrm{O}$. Cells were surface stained with fluorescence-conjugated anti-CD45, antiCD11b, anti-Ly6G, anti-MHCII, anti-F4/80, anti-Ly6C and anti-CX3CR1 antibody cocktail containing Fc block (anti-CD16/CD32) and Tris-EDTA (1 mM). Cells were then fixed (10 min, room temperature) with paraformaldehyde ( $2 \% \mathrm{w} / \mathrm{v})$. Live/Dead Fixable Blue stain was used to exclude dead cells. Samples were analysed on an LSRII flow cytometer (Becton-Dickinson) and cell populations characterised as follows:- neutrophils (CD45 hilCD11 b $\left.\mathrm{b}^{\mathrm{hi}} / \mathrm{Ly}^{\mathrm{h}} \mathrm{G}^{\mathrm{hi}}\right)$, monocyte-derived-macrophages $\quad\left(\mathrm{CD}^{\mathrm{h}} 5^{\mathrm{hi}} / \mathrm{CD} 11 \mathrm{~b}^{\mathrm{hi}} / \mathrm{Ly} 6 \mathrm{G} / \mathrm{MHCI} \mathrm{I}^{\mathrm{h}} / \mathrm{F} 4 / 80^{-}\right), \quad$ resident macrophages (CD45 hi/CD11b hi/Ly6G-/F4/80 $^{\text {hi }}$ ), Ly6C ${ }^{\text {hi }}$ monocytes (CD45 ${ }^{\text {hi }} /$ CD11 $b^{\text {hi } / L y 6 G-~}$ /MHCII/F4/80/CX3CR1 ${ }^{\text {hi/Ly6C }}{ }^{\text {hi }}$ ), using FlowJo software.

\section{Quantification and statistical analysis}

Data are presented as mean values plus the SEM. Accepted levels of significance were ${ }^{*} \mathrm{P}<$ $0.05,{ }^{* *} \mathrm{P}<0.01,{ }^{* *} \mathrm{P}<0.001,{ }^{* * * *} \mathrm{P}<0.0001$. Statistical analyses were carried out using GraphPad Prism (version 8). Data where comparisons were made against a vehicle control, a one way ANOVA was performed with a Dunnett's post hoc comparison was used. Experiments with two independent variables were analysed using a two-way ANOVA followed by a Tukey's post hoc corrected analysis. Equal variance and normality were assessed with Levene's test and the Shapiro-Wilk test, respectively, and appropriate transformations were applied when necessary. $\mathrm{n}$ represents experiments performed on individual animals or different passages for experiments involving HeLa cells.

\section{References}


1. Dinarello CA, Simon A, van der Meer JW. Treating inflammation by blocking interleukin-1 in a broad spectrum of diseases. Nature reviews Drug discovery. 2012;11(8):63352.

2. Evavold CL, Kagan JC. Inflammasomes: Threat-Assessment Organelles of the Innate Immune System. Immunity. 2019;51(4):609-24.

3. Mangan MSJ, Olhava EJ, Roush WR, Seidel HM, Glick GD, Latz E. Targeting the NLRP3 inflammasome in inflammatory diseases. Nature reviews Drug discovery. 2018;17(8):588-606.

4. Mariathasan S, Weiss DS, Newton K, McBride J, O'Rourke K, Roose-Girma M, et al. Cryopyrin activates the inflammasome in response to toxins and ATP. Nature. 2006;440(7081):228-32.

5. Perregaux DG, Laliberte RE, Gabel CA. Human monocyte interleukin-1beta posttranslational processing. Evidence of a volume-regulated response. The Journal of biological chemistry. 1996;271(47):29830-8.

6. Compan V, Baroja-Mazo A, Lopez-Castejon G, Gomez Al, Martinez CM, Angosto D, et al. Cell volume regulation modulates NLRP3 inflammasome activation. Immunity. $2012 ; 37(3): 487-500$.

7. Qiu Z, Dubin AE, Mathur J, Tu B, Reddy K, Miraglia LJ, et al. SWELL1, a plasma membrane protein, is an essential component of volume-regulated anion channel. Cell. $2014 ; 157(2): 447-58$.

8. Voss FK, Ullrich F, Munch J, Lazarow K, Lutter D, Mah N, et al. Identification of LRRC8 heteromers as an essential component of the volume-regulated anion channel VRAC. Science. 2014;344(6184):634-8.

9. Daniels MJ, Rivers-Auty J, Schilling T, Spencer NG, Watremez W, Fasolino V, et al. Fenamate NSAIDs inhibit the NLRP3 inflammasome and protect against Alzheimer's disease in rodent models. Nature communications. 2016;7:12504.

10. Green JP, Yu S, Martin-Sanchez F, Pelegrin P, Lopez-Castejon G, Lawrence CB, et al. Chloride regulates dynamic NLRP3-dependent ASC oligomerization and inflammasome 
priming. Proceedings of the National Academy of Sciences of the United States of America. 2018;115(40):E9371-E80.

11. Deneka D, Sawicka M, Lam AKM, Paulino C, Dutzler R. Structure of a volumeregulated anion channel of the LRRC8 family. Nature. 2018;558(7709):254-9.

12. Kern DM, Oh S, Hite RK, Brohawn SG. Cryo-EM structures of the DCPIB-inhibited volume-regulated anion channel LRRC8A in lipid nanodiscs. eLife. 2019;8.

13. Helix N, Strobaek D, Dahl BH, Christophersen P. Inhibition of the endogenous volumeregulated anion channel (VRAC) in HEK293 cells by acidic di-aryl-ureas. J Membr Biol. 2003;196(2):83-94

14. Droogmans G, Maertens C, Prenen J, Nilius B. Sulphonic acid derivatives as probes of pore properties of volume-regulated anion channels in endothelial cells. Br J Pharmacol. 1999;128(1):35-40.

15. Labute P. The generalized Born/volume integral implicit solvent model: estimation of the free energy of hydration using London dispersion instead of atomic surface area. J Comput Chem. 2008;29(10):1693-8.

16. Galli CL, Sensi C, Fumagalli A, Parravicini C, Marinovich M, Eberini I. A computational approach to evaluate the androgenic affinity of iprodione, procymidone, vinclozolin and their metabolites. PLoS One. 2014;9(8):e104822.

17. Galietta LJ, Haggie PM, Verkman AS. Green fluorescent protein-based halide indicators with improved chloride and iodide affinities. FEBS letters. 2001;499(3):220-4.

18. Gross CJ, Mishra R, Schneider KS, Medard G, Wettmarshausen J, Dittlein DC, et al. K+ Efflux-Independent NLRP3 Inflammasome Activation by Small Molecules Targeting Mitochondria. Immunity. 2016;45(4):761-73.

19. Kumar L, Chou J, Yee CS, Borzutzky A, Vollmann EH, von Andrian UH, et al. Leucinerich repeat containing $8 \mathrm{~A}$ (LRRC8A) is essential for $\mathrm{T}$ lymphocyte development and function. The Journal of experimental medicine. 2014;211(5):929-42. 
20. Yona S, Kim KW, Wolf Y, Mildner A, Varol D, Breker M, et al. Fate mapping reveals origins and dynamics of monocytes and tissue macrophages under homeostasis. Immunity. 2013;38(1):79-91.

21. Verhoef PA, Kertesy SB, Lundberg K, Kahlenberg JM, Dubyak GR. Inhibitory effects of chloride on the activation of caspase-1, IL-1beta secretion, and cytolysis by the P2X7 receptor. Journal of immunology. 2005;175(11):7623-34.

22. Littler DR, Harrop SJ, Goodchild SC, Phang JM, Mynott AV, Jiang L, et al. The enigma of the CLIC proteins: Ion channels, redox proteins, enzymes, scaffolding proteins? FEBS letters. 2010;584(10):2093-101.

23. Argenzio E, Moolenaar $\mathrm{WH}$. Emerging biological roles of $\mathrm{Cl}$ - intracellular channel proteins. Journal of cell science. 2016;129(22):4165-74.

24. Domingo-Fernandez R, Coll RC, Kearney J, Breit S, O'Neill LAJ. The intracellular chloride channel proteins CLIC1 and CLIC4 induce IL-1beta transcription and activate the NLRP3 inflammasome. The Journal of biological chemistry. 2017;292(29):12077-87.

25. Tang T, Lang X, Xu C, Wang X, Gong T, Yang Y, et al. CLICs-dependent chloride efflux is an essential and proximal upstream event for NLRP3 inflammasome activation. Nature communications. 2017;8(1):202.

26. Coll RC, Hill JR, Day CJ, Zamoshnikova A, Boucher D, Massey NL, et al. MCC950 directly targets the NLRP3 ATP-hydrolysis motif for inflammasome inhibition. Nature chemical biology. 2019;15(6):556-9.

27. Tapia-Abellan A, Angosto-Bazarra D, Martinez-Banaclocha H, de Torre-Minguela C, Ceron-Carrasco JP, Perez-Sanchez H, et al. MCC950 closes the active conformation of NLRP3 to an inactive state. Nature chemical biology. 2019;15(6):560-4.

28. Jiang $\mathrm{H}, \mathrm{He} \mathrm{H}$, Chen $\mathrm{Y}$, Huang W, Cheng J, Ye J, et al. Identification of a selective and direct NLRP3 inhibitor to treat inflammatory disorders. The Journal of experimental medicine. $2017 ; 214(11): 3219-38$.

29. Laliberte RE, Perregaux DG, Hoth LR, Rosner PJ, Jordan CK, Peese KM, et al. Glutathione s-transferase omega 1-1 is a target of cytokine release inhibitory drugs and may 
be responsible for their effect on interleukin-1beta posttranslational processing. The Journal of biological chemistry. 2003;278(19):16567-78.

30. Yang H, Wang H, Shivalila CS, Cheng AW, Shi L, Jaenisch R. One-step generation of mice carrying reporter and conditional alleles by CRISPR/Cas-mediated genome engineering. Cell. 2013;154(6):1370-9.

31. Gurumurthy CB, O'Brien AR, Quadros RM, Adams J, Jr., Alcaide P, Ayabe S, et al. Reproducibility of CRISPR-Cas9 methods for generation of conditional mouse alleles: a multicenter evaluation. Genome biology. 2019;20(1):171.

32. Hodgkins A, Farne A, Perera S, Grego T, Parry-Smith DJ, Skarnes WC, et al. WGE: a CRISPR database for genome engineering. Bioinformatics. 2015;31(18):3078-80.

33. Demayo JL, Wang J, Liang D, Zhang R, Demayo FJ. Genetically Engineered Mice by Pronuclear DNA microinjection. Curr Protoc Mouse Biol. 2012;2:245-62.

34. Kaneko T. Genome Editing in Mouse and Rat by Electroporation. Methods in molecular biology. 2017;1630:81-9.

\section{Acknowledgments}

This work was supported by Medical Research Council Grants MR/N029992/1 and MR/T0116515/1 (to D.B.), The Alzheimer's Society AS-PhD-16-002 (to D.B.) and by a Presidential Fellowship (University of Manchester, to J.G.). 


\section{Figure Legends}

Figure 1 - Modelling of proposed VRAC inhibitors on the crystal structure of LRRC8 channels. (A) Hexameric cryo-EM structure of VRAC with bound DCPIB (PDB: 6NZW) (B, DI) docked VRAC inhibitors (orange) in the VRAC Arg103 extracellular selectivity filter. Protein surface colored according to hydrophilic (blue), hydrophobic regions (red) and neutral regions (white). (B) Side-view of docked DCPIB superimposed on the cryo-EM DCPIB pose (black) (C) MM/GBVI binding energies and top-view of cryo-EM pose of DCPIB (black) in VRAC (-5.2 $\left.\mathrm{kcal} \mathrm{mol}^{-1}\right)(\mathbf{D})$ flufenamic acid $\left(-5.1 \mathrm{kcal} \mathrm{mol}^{-1}\right)(\mathbf{E})$ mefenamic acid $\left(-5.2 \mathrm{kcal} \mathrm{mol}^{-1}\right)(\mathbf{F})$ MONNA $\left(-5.8 \mathrm{kcal} \mathrm{mol}^{-1}\right)(\mathbf{G}) \mathrm{NS} 3728\left(-6.4 \mathrm{kcal} \mathrm{mol}^{-1}\right) \mathbf{( H )} 4-$ sulfonic calix(6)arene $\left(-9.9 \mathrm{kcal} \mathrm{mol}^{-1}\right)$ (I) tamoxifen $\left(-6.5 \mathrm{kcal} \mathrm{mol}^{-1}\right)$.

Figure 2 - VRAC inhibitors block hypotonicity-induced $\mathrm{Cl}^{-}$channel opening and regulatory volume decrease (RVD). (A) $\mathrm{Cl}^{-}$channel opening measured in HeLa cells transiently expressing the halide-sensitive EYFP (H148Q/1152L). HeLa cells were pre-treated with a vehicle control (DMSO) or DCPIB $(10 \mu \mathrm{M})$ and incubated in an isotonic (310 mOsm kg$\left.{ }^{1}\right)$ or hypotonic $\left(215 \mathrm{mOsm} \mathrm{kg}^{-1}\right)$ solution for 5 minutes before quenching by addition of $\mathrm{Nal}$ (40 mM). (B) Normalised EYFP (H148Q/l152L) fluorescence values from HeLa cells pretreated with either a vehicle control (DMSO), tamoxifen (Tam, $10 \mu \mathrm{M})$, 4-sulfonic calix(6)arene (Calix, $100 \mu \mathrm{M})$, MONNA (MON, $50 \mu \mathrm{M})$, DCPIB $(10 \mu \mathrm{M})$, flufenamic acid (FFA, $100 \mu \mathrm{M})$ or NS3728 (NS3, $10 \mu \mathrm{M})$. Cells were incubated an isotonic $\left(310 \mathrm{mOsm} \mathrm{kg}^{-1}\right)$ or hypotonic $(215$ mOsm $\mathrm{kg}^{-1}$ ) solution for 5 minutes before quenching by addition of Nal. Fluorescent measurement was taken 30 seconds after Nal addition $(n=6-12)$. (C) Relative cell size of murine bone marrow derived macrophages (BMDMs) incubated in isotonic (340 mOsm $\left.\mathrm{kg}^{-1}\right)$ or hypotonic (117 mOsm $\mathrm{kg}^{-1}$ ) solution, pre-treated with a vehicle control (DMSO) or DCPIB $(10 \mu \mathrm{M})$. BMDMs were labelled with the fluorescent dye calcein and area of fluorescence was measured over time. (D) Area under the curve of BMDMs incubated in a hypotonic solution 
$\left(117 \mathrm{mOsm} \mathrm{kg}{ }^{-1}\right)$ in the presence of either a vehicle control (DMSO), tamoxifen (Tam, $\left.10 \mu \mathrm{M}\right)$, 4-sulfonic calix(6)arene (Calix, $100 \mu \mathrm{M})$, MONNA (MON, $20 \mu \mathrm{M})$, DCPIB $(10 \mu \mathrm{M})$, flufenamic acid (FFA, $100 \mu \mathrm{M})$ or NS3728 (NS3, $10 \mu \mathrm{M})(\mathrm{n}=3) .{ }^{*} p<0.05,{ }^{* *} p<0.01,{ }^{* * *} p<0.01$ determined by a one-way ANOVA with Dunnett's (vs vehicle control) post hoc analysis. Values shown are mean plus the SEM.

Figure 3 - VRAC inhibitors differentially regulate NLRP3. (A) IL-1 $\beta$ release was determined by ELISA on supernatants from murine bone marrow derived macrophages (BMDMs). LPS-primed (1 $\left.\mu \mathrm{g} \mathrm{mL}^{-1}, 4 \mathrm{~h}\right)$ BMDMs were pre-treated with either a vehicle control (DMSO), tamoxifen (Tam, $10 \mu \mathrm{M}$ ), 4-sulfonic calix(6)arene (Calix, $100 \mu \mathrm{M}$ ), MONNA (MON, $50 \mu \mathrm{M})$, DCPIB $(10 \mu \mathrm{M})$, flufenamic acid (FFA, $100 \mu \mathrm{M})$ or NS3728 (NS3, $10 \mu \mathrm{M})$ before stimulation with ATP ( $5 \mathrm{mM}, 2 \mathrm{~h})(\mathrm{n}=6)$. (B) Cell death determined by an LDH assay of cells treated in (A). (C) Western blot of Triton $\mathrm{x}-100$ insoluble crosslinked ASC oligomers and soluble total BMDM cell lysates (cell lysate + supernatant) probed for ASC, GSDMD, caspase1 and IL-1 $\beta$. LPS-primed $\left(1 \mu \mathrm{g} \mathrm{mL}^{-1}, 4 \mathrm{~h}\right)$ BMDMs were pre-treated with either a vehicle control (DMSO), tamoxifen (Tam, $10 \mu \mathrm{M}$ ), 4-sulfonic calix(6)arene (Calix, $100 \mu \mathrm{M}$ ), MONNA (MON, $50 \mu \mathrm{M})$, DCPIB $(10 \mu \mathrm{M})$, flufenamic acid (FFA, $100 \mu \mathrm{M})$, NS3728 (NS3, $10 \mu \mathrm{M})$ or the NLRP3 inhibitors MCC950 (MCC, $10 \mu \mathrm{M})$ and NBC19 (NBC, $10 \mu \mathrm{M})$ before stimulation with ATP (5 $\mathrm{mM}, 2 \mathrm{~h})(\mathrm{n}=3)$. (D) IL-1 $\beta$ release from LPS-primed $\left(1 \mu \mathrm{g} \mathrm{mL} \mathrm{L}^{-1}, 4 \mathrm{~h}\right)$ BMDMs pre-treated with a vehicle control (DMSO), flufenamic acid (FFA, $100 \mu \mathrm{M})$ or NS3728 (NS3, $10 \mu \mathrm{M})$ before stimulation with nigericin $(10 \mu \mathrm{M}, 2 \mathrm{~h})(\mathrm{n}=6)$. (E) IL-1 $\beta$ release from LPS-primed $\left(1 \mu \mathrm{g} \mathrm{mL}^{-1}, 4\right.$ h) BMDMs pre-treated with a vehicle control (DMSO), flufenamic acid (FFA, $100 \mu \mathrm{M}$ ) or NS3728 (NS3, $10 \mu \mathrm{M})$ before stimulation with imiquimod $(75 \mu \mathrm{M}, 2 \mathrm{~h})(\mathrm{n}=6)$. (F) Western blot of Triton x-100 insoluble crosslinked ASC oligomers and soluble total BMDM cell lysates (cell lysate + supernatant) probed for ASC, GSDMD, and caspase-1. LPS-primed (1 $\left.\mu \mathrm{g} \mathrm{mL}^{-1}, 4 \mathrm{~h}\right)$ BMDMs were pre-treated with either a vehicle control (DMSO), flufenamic acid (FFA, $100 \mu \mathrm{M})$, NS3728 (NS3, $10 \mu \mathrm{M})$, the NLRP3 inhibitor MCC950 (MCC, $10 \mu \mathrm{M})$ or $\mathrm{KCl}\left(\mathrm{K}^{+}, 25 \mathrm{mM}\right)$ before 
stimulation with nigericin $(10 \mu \mathrm{M}, 2 \mathrm{~h})$ or imiquimod $(75 \mu \mathrm{M}, 2 \mathrm{~h})(\mathrm{n}=3) .{ }^{*} p<0.05,{ }^{* *} p<0.01$, determined by a one-way ANOVA with Dunnett's (vs vehicle control) post hoc analysis. Values shown are mean plus the SEM.

Figure 4 - Lrrc8a KO macrophages are unable to undergo hypotonicity-induced regulatory volume decrease (RVD). (A) Generation of LRRC8A conditional allele. LRRC8A is found on mouse chromosome 2 and consists of 4 exons. Untranslated sequences are represented by black boxes, and coding sequences by grey boxes. Exon 2 contains the vast majority of coding sequence and was flanked by loxP sites in two sequential steps, first integrating the $5^{\prime}$ LoxP by CRISPR-Cas9 (scissors) mediated double strand break and the supply of a homology flanked ssODN repair template containing the loxP site (grey triangle). This 5' fl background was then bred to establish a colony and the process repeated to integrate the second 3' loxP on this background. At each step integration of loxP was confirmed by PCR and Sanger sequencing. Finally crossing with a Cre driver knocked into the $C \times 3 c r 1$ locus results in recombinase mediated excision of Exon 2. (B) Western blot of LRRC8A from wildtype (WT) or Lrrc8a knockout (KO) bone marrow derived macrophages (BMDMs) and peritoneal macrophages $(M \phi)(n=3)$. (C) Regulatory volume decrease measured by calcein fluorescence in WT or Lrrc8a KO BMDMs incubated in a hypotonic buffer (117 mOsm $\mathrm{kg}^{-1}$ ) $(n=4-5)$. (D) Area under the curve (AUC) analysis of (C) $(n=4-5)$. (E) Representative phase contrast images of WT or Lrrc8a KO BMDMs incubated in a hypotonic buffer $(117 \mathrm{mOsm} \mathrm{kg}$ $\left.{ }^{1}\right)$ at indicated time points $(n=3$, Scale $=20 \mu \mathrm{m}) .{ }^{* \star} p<0.001$ determined by an unpaired $t$-test. Values shown are mean plus the SEM.

Figure 5 - LRRC8A is dispensable for activation of the NLRP3 inflammasome. (A) IL-1 $\beta$ release was determined by ELISA on supernatants from wild-type (WT) or Lrrc8a knockout (KO) bone marrow derived macrophages (BMDMs). Naïve or LPS-primed (1 $\mu \mathrm{g} \mathrm{mL}^{-1}, 4 \mathrm{~h}$ ) 
BMDMs were stimulated with either vehicle, ATP $(5 \mathrm{mM})$, nigericin (Nig, $10 \mu \mathrm{M})$, silica (300 $\left.\mu \mathrm{g} \mathrm{mL} \mathrm{L}^{-1}\right)$ or imiquimod (IQ, $\left.75 \mu \mathrm{M}\right)$ for $2 \mathrm{~h}(\mathrm{n}=5)$. (B) Cell death determined by an LDH assay of cells treated in (A) $(n=3)$. (C) Western blot of Triton $x-100$ insoluble crosslinked ASC oligomers and soluble total BMDM cell lysates (cell lysate + supernatant) probed for ASC and caspase-1. LPS-primed (1 $\left.\mathrm{g} \mathrm{mL}^{-1}, 4 \mathrm{~h}\right)$ WT or Lrrc8a KO BMDMs were stimulated with either nigericin (Nig, $10 \mu \mathrm{M})$, ATP $(5 \mathrm{mM})$ or imiquimod (IQ, $75 \mu \mathrm{M})$ for $2 \mathrm{~h}(\mathrm{n}=3)$. (D) IL-1 $\beta$ release from LPS-primed (1 $\left.\mu \mathrm{g} \mathrm{mL}^{-1}, 4 \mathrm{~h}\right) \mathrm{WT}$ or Lrrc8a KO BMDMs pre-treated with a vehicle control (DMSO), flufenamic acid (FFA, $100 \mu \mathrm{M}$ ) or NS3728 (NS3, $10 \mu \mathrm{M})$ and then stimulated with ATP $(5 \mathrm{mM})$ or nigericin $(10 \mu \mathrm{M})$ for $2 \mathrm{~h}(\mathrm{n}=3)$. (E) Western blot of Triton $\mathrm{x}-100$ insoluble crosslinked ASC oligomers and soluble total BMDM cell lysates (cell lysate + supernatant) probed for ASC, caspase-1 and IL-1 $\beta$. LPS-primed $\left(1 \mu \mathrm{g} \mathrm{mL}{ }^{-1}, 4 \mathrm{~h}\right) \mathrm{WT}$ or Lrrc8a KO BMDMs were pre-treated with a vehicle control, flufenamic acid (FFA, $100 \mu \mathrm{M})$ or NS3728 (NS3, 10 $\mu \mathrm{M})$ and stimulated with nigericin $(10 \mu \mathrm{M}, 2 \mathrm{~h})(\mathrm{n}=5)$. (F-G) IL-1 $\beta$ detected by ELISA in the peritoneal lavage $(F)$ or plasma $(G)$ from WT mice. Mice were pre-treated intraperitoneally (i.p.) with a vehicle control, NS3728 (NS3, $50 \mathrm{mg} \mathrm{kg}^{-1}$ ) or MCC950 (MCC, $50 \mathrm{mg} \mathrm{kg}^{-1}$ ) and LPS $(1 \mu \mathrm{g}) .4 \mathrm{~h}$ after injection with LPS, mice were anaesthetised and injected with additional vehicle control, NS3728 (NS3, $50 \mathrm{mg} \mathrm{kg}^{-1}$ ) or MCC950 (MCC, $50 \mathrm{mg} \mathrm{kg}^{-1}$ ) before i.p. injection of ATP $(100 \mathrm{mM}, 500 \mu \mathrm{L}, 15 \mathrm{~min})(\mathrm{n}=5)$. (H-I) IL-1 $\beta$ detected by ELISA in the peritoneal lavage (H) or plasma (I) from Lrrc8a KO and WT littermates as treated in $(F)(n=3-5) .{ }^{* *} p<0.01$, ${ }^{* * *} p<0.001,{ }^{* * *} p<0.0001$ determined by a one-way ANOVA with Dunnett's (vs vehicle control) post hoc analysis $(F, G)$ or a two-way ANOVA with Tukey's post hoc analysis $(A, B, D, H, I)$. Values shown are mean_plus the SEM.

Figure 6 - LRRC8a is an essential component of hypotonicity-induced NLRP3 activation. (A) IL-1 $\beta$ release was determined by ELISA on supernatants from wild-type (WT) or Lrrc8a knockout (KO) bone marrow derived macrophages (BMDMs). LPS-primed (1 $\mu \mathrm{g} \mathrm{mL}$ 1, 4 h) wild type (WT) or Lrrc8a knockout (KO) BMDMs were incubated in either an isotonic 
buffer (340 mOsm kg-1), hypotonic buffer $\left(117 \mathrm{mOsm} \mathrm{kg}^{-1}\right)$ or isotonic buffer with ATP $(5 \mathrm{mM})$ for $4 \mathrm{~h}(\mathrm{n}=5)$. (B) Cell death determined by an LDH assay of cells treated in (A). (C) Western blot of total BMDM cell lysates (cell lysate + supernatant) probed for IL-1 $\beta$, caspase-1 and LRRC8a. LPS-primed ( $\left.1 \mu \mathrm{g} \mathrm{mL}^{-1}, 4 \mathrm{~h}\right)$ WT or Lrrc8a KO BMDMs were pre-treated with a vehicle control or a NLRP3 inhibitor MCC950 (MCC, $10 \mu \mathrm{M})$ before incubation in either an isotonic buffer (340 mOsm kg-1), hypotonic buffer $\left(117 \mathrm{mOsm} \mathrm{kg}^{-1}\right)$ or isotonic buffer with ATP (5 mM) for $4 \mathrm{~h}$. (D) Western blot of Triton x-100 insoluble crosslinked ASC oligomers and soluble total BMDM cell lysates (cell lysate + supernatant) probed for ASC. LPS-primed (1 $\mu \mathrm{g}$ $\mathrm{mL}^{-1}, 4 \mathrm{~h}$ ) WT or Lrrc8a KO BMDMs were pre-treated with a vehicle control or MCC950 (MCC, $10 \mu \mathrm{M})$ and incubated in either an isotonic buffer (340 mOsm $\left.\mathrm{kg}^{-1}\right)$, hypotonic buffer (117 mOsm $\left.\mathrm{kg}^{-1}\right)$ for $4 \mathrm{~h}(\mathrm{n}=3) .{ }^{* *} p<0.01$ determined by a two-way ANOVA with Tukey's post hoc analysis. Values shown are mean plus the SEM.

Supplementary Figure 1 - (A) Top view and (B) side view of the cryo-EM structure of DCPIB in the arginine pore of VRAC (C-I). Molecular surfaces coloured by electrostatic potential for the docked poses of VRAC inhibitors, indicating regions of negative (red) and positive (blue) potential. (C) cryo-EM pose of DCPIB. Docked poses of (D) flufenamic acid (E) mefenamic acid (F) MONNA (G) NS3728 (H) 4-sulfonic calix(6)arene and (I) tamoxifen.

Supplementary Figure 2 - Dose-response curve for DCPIB. IL-1 $\beta$ release detected by ELISA on supernatants from LPS-primed $\left(1 \mu \mathrm{g} \mathrm{mL} \mathrm{L}^{-1}, 4 \mathrm{~h}\right)$ bone marrow derived macrophages (BMDM) pre-treated with the indicated dose of DCPIB $(0.03-100 \mu \mathrm{M}, 15 \mathrm{~min})$ before stimulation with ATP $(5 \mathrm{mM})$, nigericin $(10 \mu \mathrm{M})$ or silica $\left(300 \mu \mathrm{g} \mathrm{mL^{-1 }}\right)$ for $2 \mathrm{~h}(\mathrm{n}=6)$. Experiments with different stimuli were performed in parallel. IL-1 $\beta$ release was normalised to that of vehicle (DMSO)-treated BMDMs. Dose-response curves were fitted using a three parameter logistical (3PL) model. Values shown are mean plus the SEM. 
Supplementary Figure 3 - Loss of LRRC8a does not affect myeloid populations in the peritoneum. (A-B) IL-6 detected by ELISA in the peritoneal lavage (A) or plasma (B) from wild-type mice. Mice were pre-treated intraperitoneally (i.p.) with a vehicle control, NS3728 (NS3, $50 \mathrm{mg} \mathrm{kg}^{-1}$ ) or MCC950 (MCC, $50 \mathrm{mg} \mathrm{kg}^{-1}$ ) and LPS $(1 \mu \mathrm{g}) .4 \mathrm{~h}$ after injection with LPS, mice were anaesthetised and injected with additional vehicle control, NS3728 (NS3, 50 mg $\mathrm{kg}^{-1}$ ) or MCC950 (MCC, $50 \mathrm{mg} \mathrm{kg}^{-1}$ ) before i.p. injection of ATP (100 mM, $500 \mu \mathrm{L}, 15 \mathrm{~min}$ ) $(n=5)$. NS3728 treatment did not significantly alter IL-6 levels. Injection of MCC950 significantly enhanced IL-6 release in the peritoneum and plasma compared to vehicle. (C-G) Flow cytometry of immune cells in naïve peritoneal lavage from WT or Lrrc8a KO mice (n=35). Representative gating strategy (C) and quantification of immune cells (D-G). Immune cells were initially gated on CD45 $5^{\text {ve }} / C D 11 b^{+v e}$ cells and cell populations were identified as follows: neutrophils (LY6G $\left.{ }^{\text {hi }}\right)$, monocyte-derived-macrophages (MDMs) (LY6G-ve/MHCII $/$ h4 $\left.4 / 80^{-v e}\right)$,

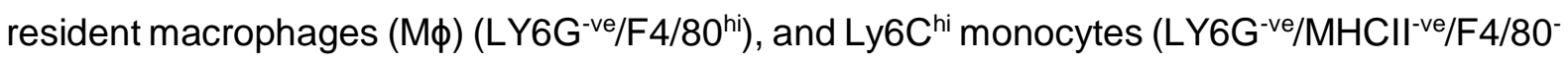
ve/CX3CR $1^{\text {hi}} /$ Ly $\left.6 C^{\text {hi }}\right)$. ns not significant, ${ }^{* *} p<0.01$ determined by a one-way ANOVA with Dunnett's (vs vehicle control) post hoc analysis $(A, B)$ or an unpaired $t$-test (D-G). Values shown are mean plus the SEM.

\section{Supplementary video 1 - Phase contrast time-lapse of the regulatory volume decrease} of wild-type (WT) littermate bone marrow-derived macrophages (BMDMs). WT BMDMs were incubated in an isotonic buffer $\left(340 \mathrm{mOsm} \mathrm{kg}^{-1}\right)$ for 5 minutes before dilution to a hypotonic solution $\left(117 \mathrm{mOsm} \mathrm{kg}^{-1}\right)$ for the duration of the recording. Images were captured every minute $(n=3$, Scale $=20 \mu m)$.

Supplementary video 2 - Phase contrast time-lapse of the regulatory volume decrease of Lrrc8a knockout (KO) bone marrow-derived macrophages (BMDMs). Lrrc8a KO 
bioRxiv preprint doi: https://doi.org/10.1101/2020.06.11.146225; this version posted June 12, 2020. The copyright holder for this preprint (which was not certified by peer review) is the author/funder, who has granted bioRxiv a license to display the preprint in perpetuity. It is made available under aCC-BY 4.0 International license.

BMDMs were incubated in an isotonic buffer $\left(340 \mathrm{mOsm} \mathrm{kg}^{-1}\right)$ for 5 minutes before dilution to a hypotonic solution (117 $\left.\mathrm{mOsm} \mathrm{kg}^{-1}\right)$ for the duration of the recording. Images were captured every minute $(n=3$, Scale $=20 \mu m)$. 
bioRxiv preprint doi: https://doi.org/10.1101/2020.06.11.146225. this version posted June 12, 2020. The copyright holder for this preprint (which was not certified by peer review) is the author/funder, who has granted bioRxiv a license to display the preprint in perpetuity. It is made available under aCC-BY 4.0 International license.

\section{Figure 1}

A

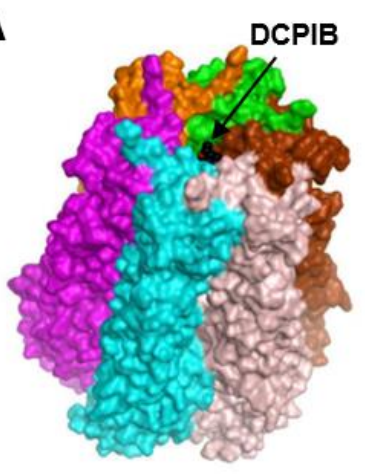

D

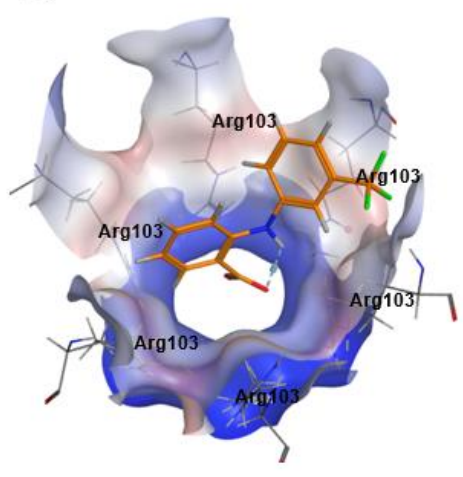

G

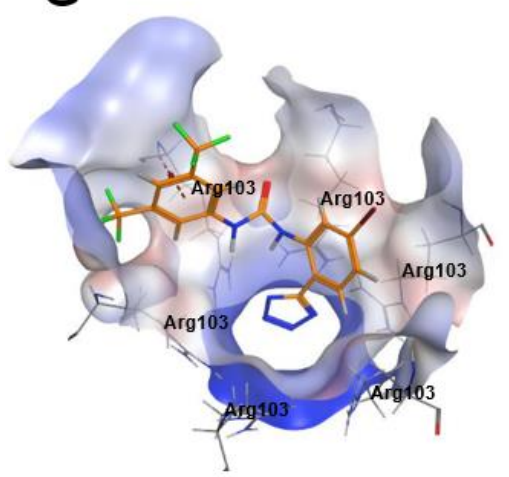

B

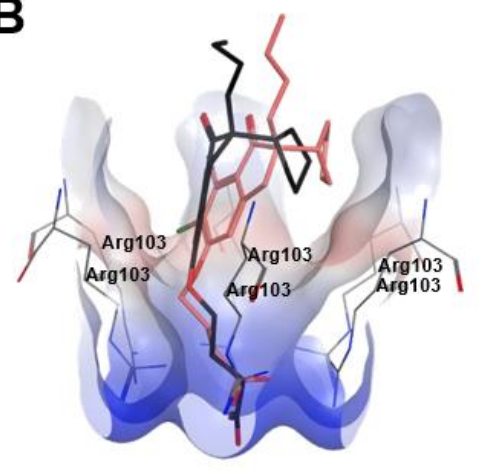

E

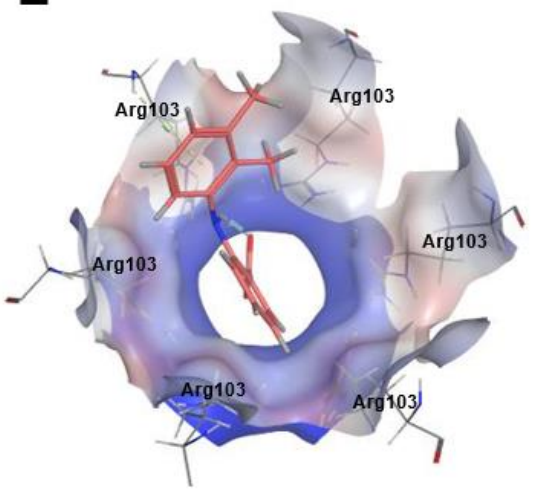

H

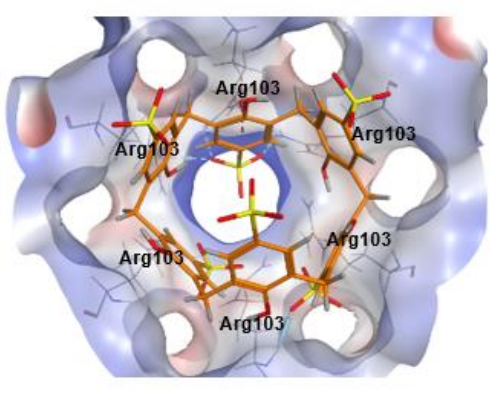

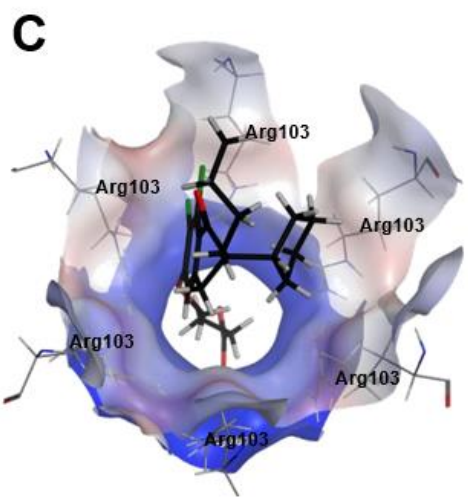

$\mathbf{F}$

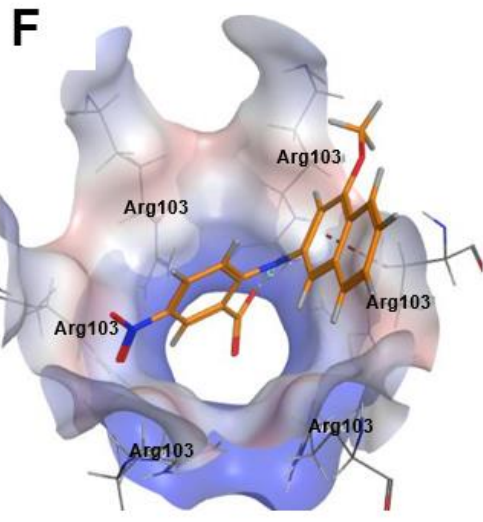

I

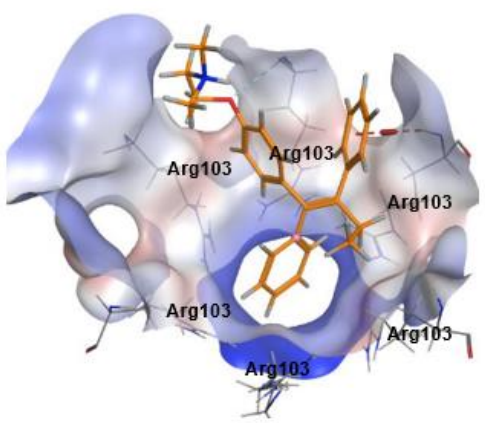


bioRxiv preprint doi: https://doi org/10.1101/2020.06.11.146225; this version posted June 12, 2020. The copyright holder for this preprint (which was not certified by peer review) is the author/funder, who has granted bioRxiv a license to display the preprint in perpetuity. It is made available under aCC-BY 4.0 International license.

\section{Figure 2}

A

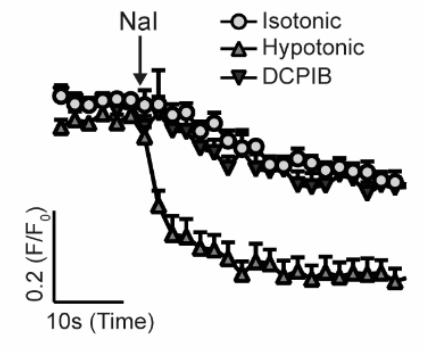

C

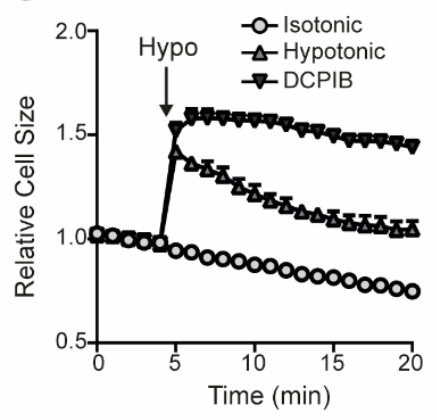

B

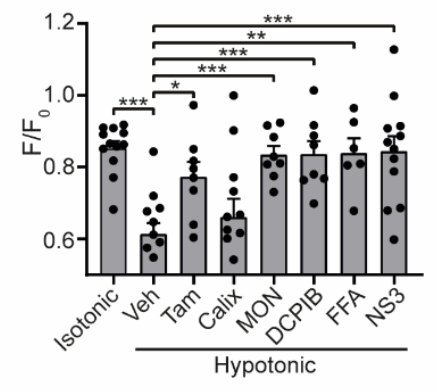

D

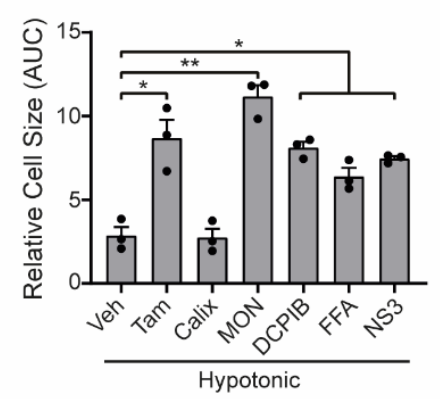


bioRxiv preprint doi: https://doi.org/10.1101/2020.06 11.146225. this version posted June 12, 2020. The copyright holder for this preprint (which was not certified by peer review) is the author/funder, who has granted bioRxiv a license to display the preprint in perpetuity. It is made available under aCC-BY 4.0 International license.

\section{Figure 3}
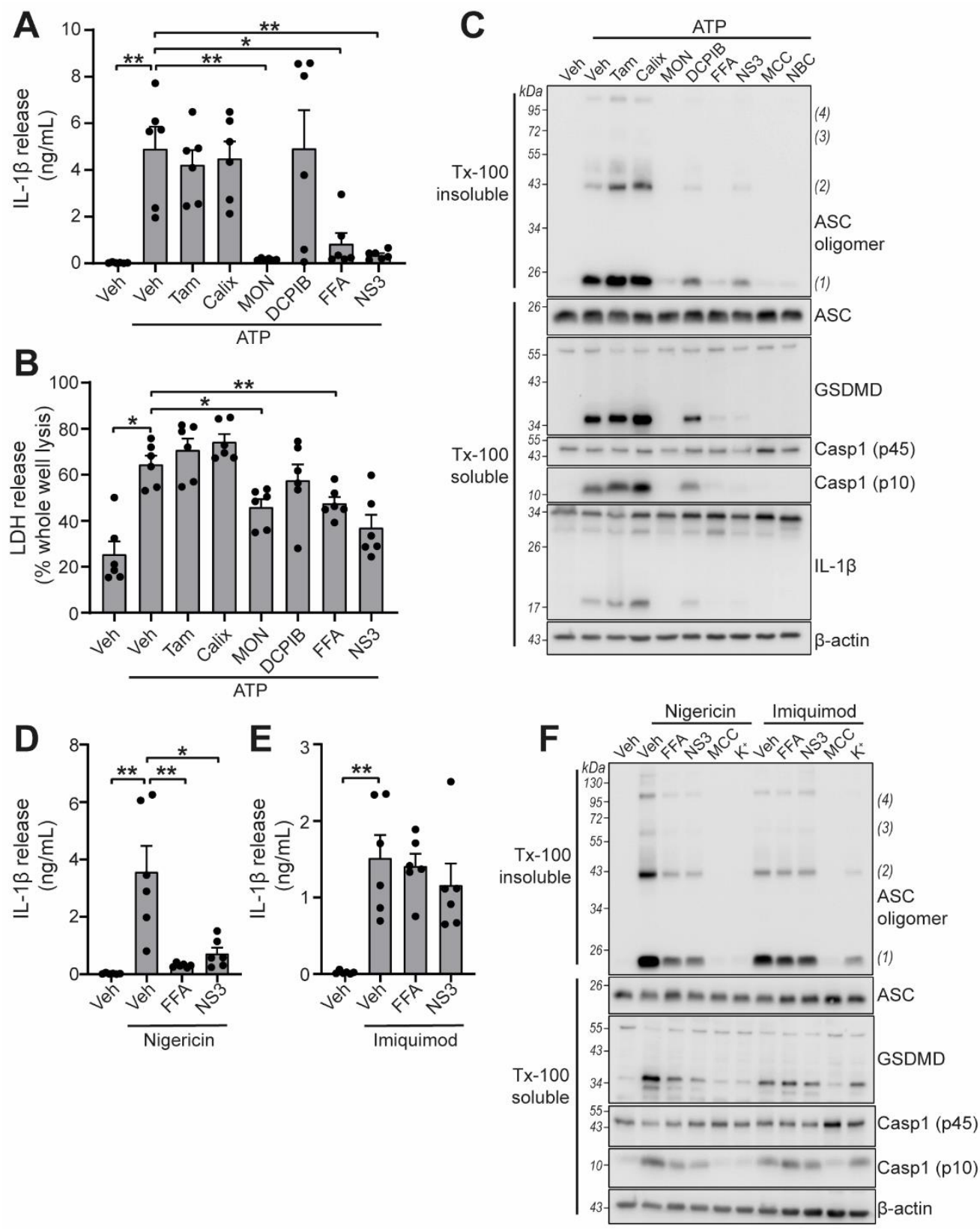
bioRxiv preprint doi: https://doi.org/10.1101/2020.06.11.146225; this version posted June 12, 2020. The copyright holder for this preprint (which was not certified by peer review) is the author/funder, who has granted bioRxiv a license to display the preprint in perpetuity. It is made available under aCC-BY 4.0 International license.

\section{Figure 4}

\section{A}
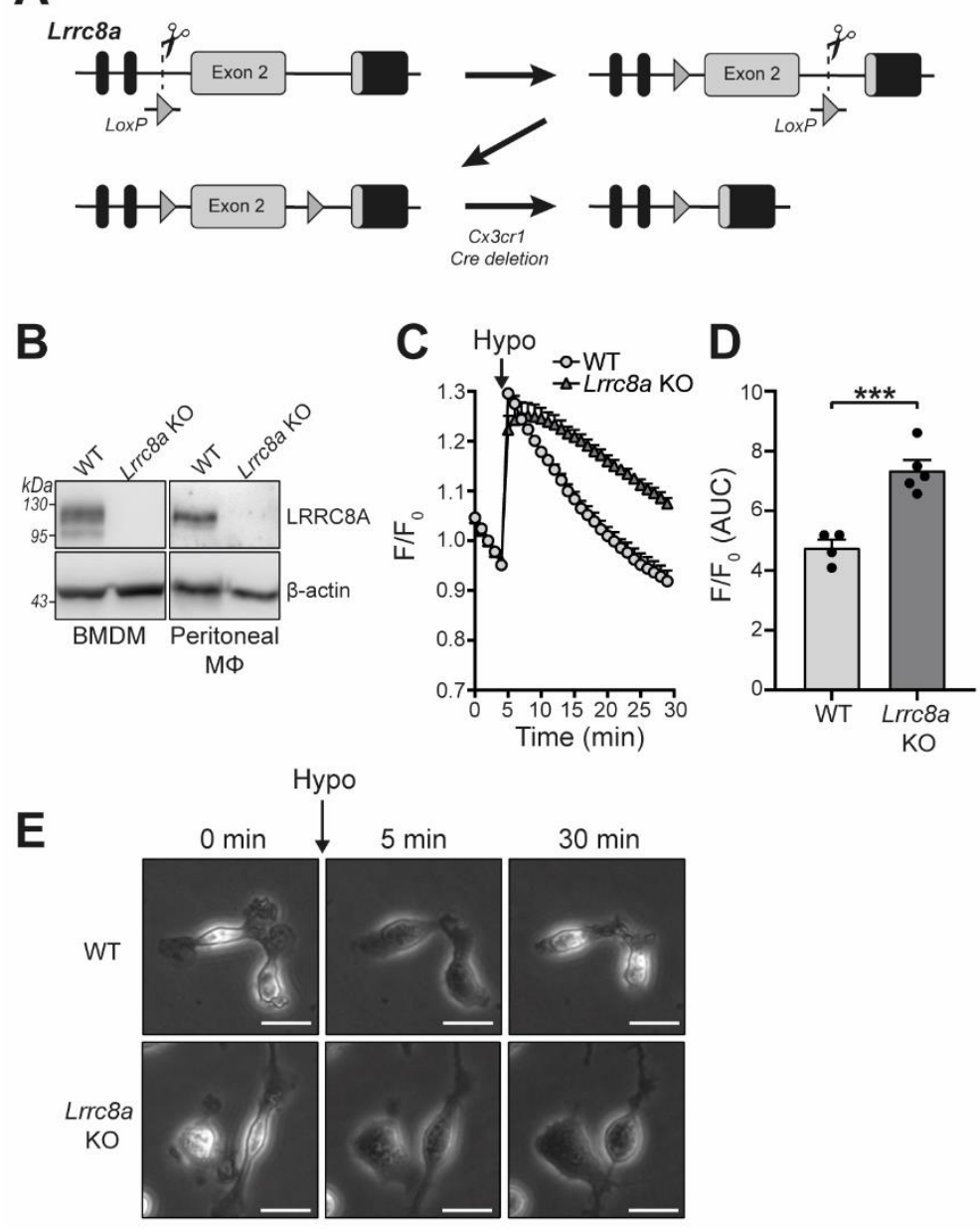
bioRxiv preprint doi: https://doi.org/10.1101/2020.06 11.146225. this version posted June 12, 2020. The copyright holder for this preprint (which was not certified by peer review) is the author/funder, who has granted bioRxiv a license to display the preprint in perpetuity. It is made available under aCC-BY 4.0 International license.

\section{Figure 5}

A
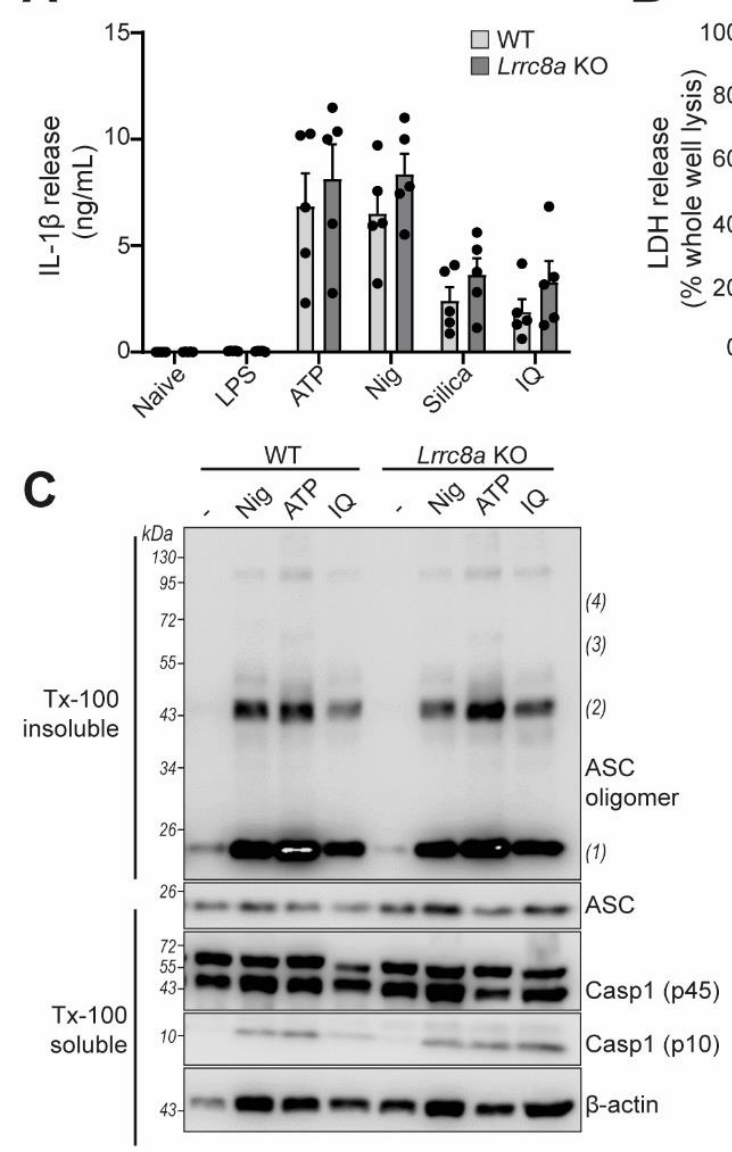

E

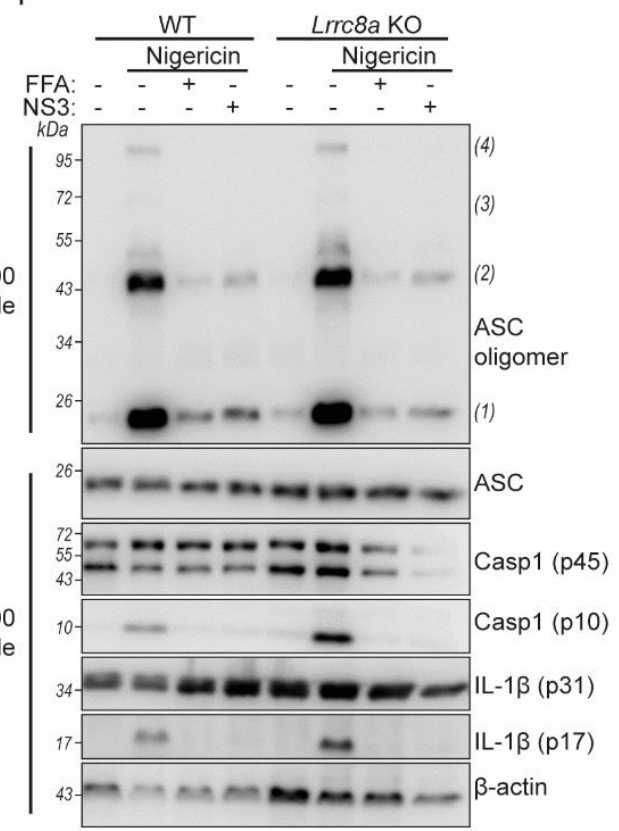

B
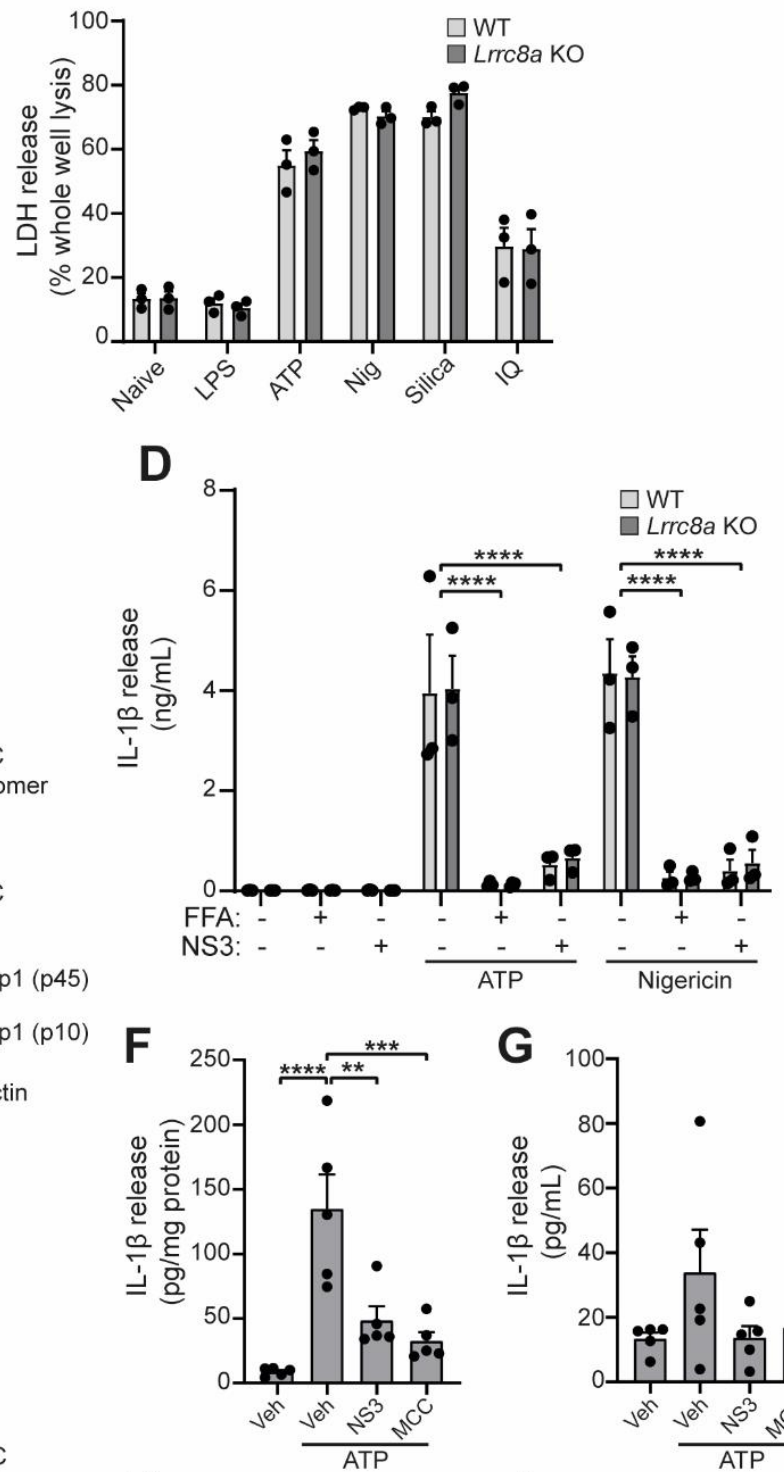

H I
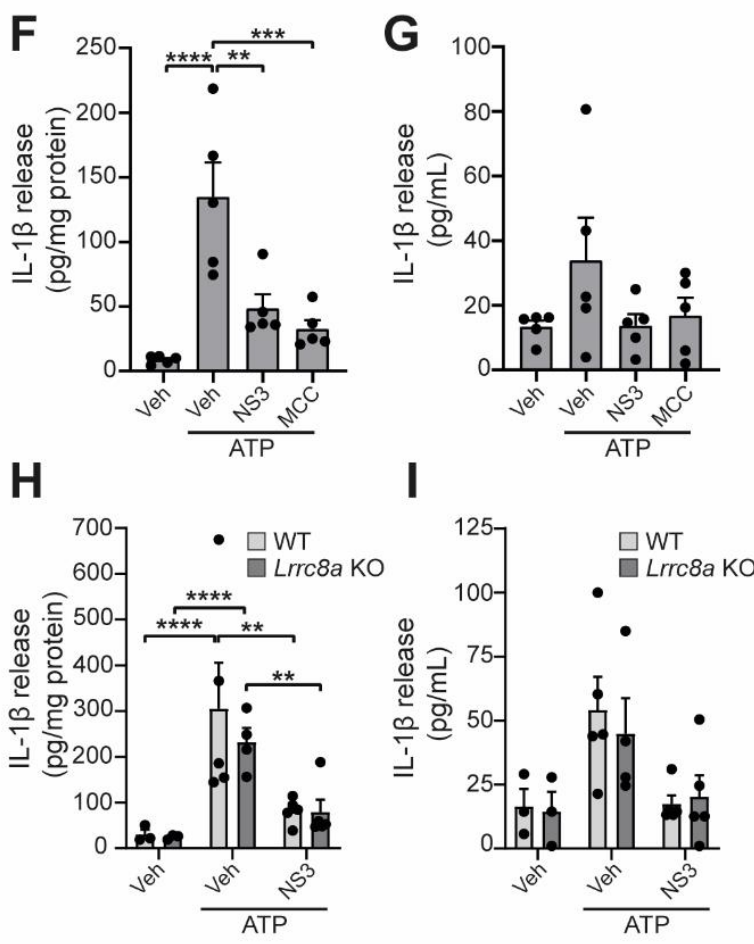
bioRxiv preprint doi: https://doi.org/10.1101/2020.06.11.146225; this version posted June 12, 2020. The copyright holder for this preprint (which was not certified by peer review) is the author/funder, who has granted bioRxiv a license to display the preprint in perpetuity. It is made available under aCC-BY 4.0 International license.

\section{Figure 6}

A

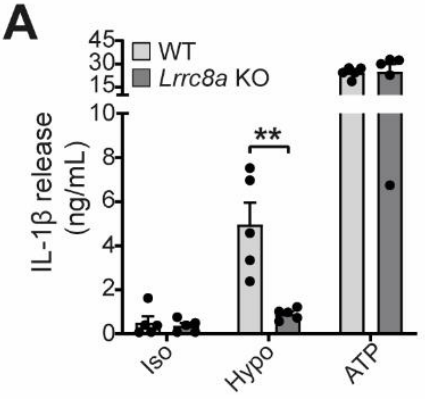

B

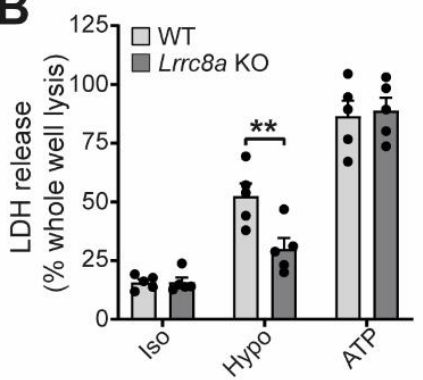

C

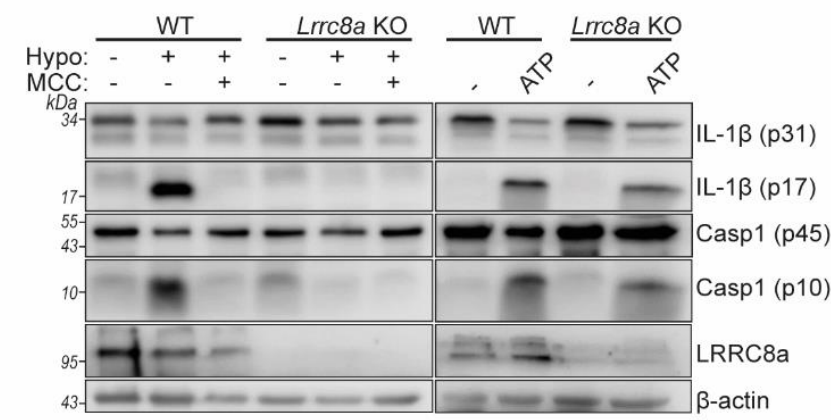

D

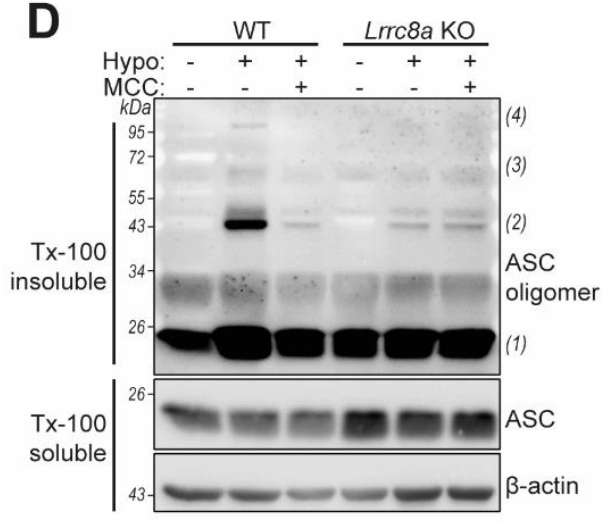


bioRxiv preprint doi: https://doi.org/10.1101/2020.06.11.146225; this version posted June 12, 2020. The copyright holder for this preprint (which was not certified by peer review) is the author/funder, who has granted bioRxiv a license to display the preprint in perpetuity. It is made available under aCC-BY 4.0 International license.

\section{Figure S1}

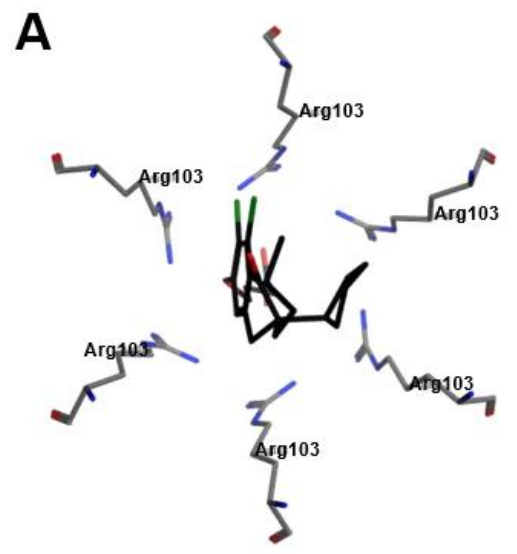

D

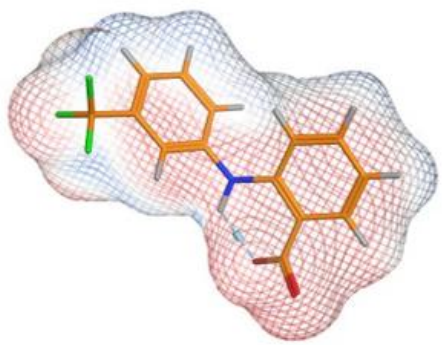

G

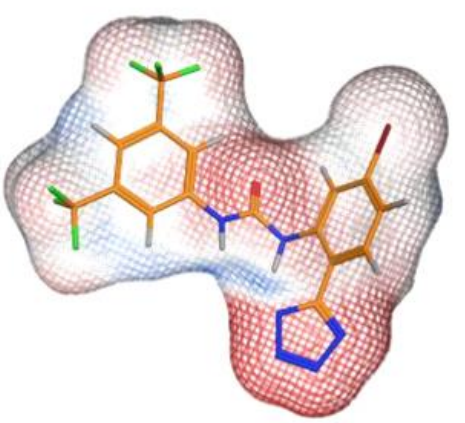

B

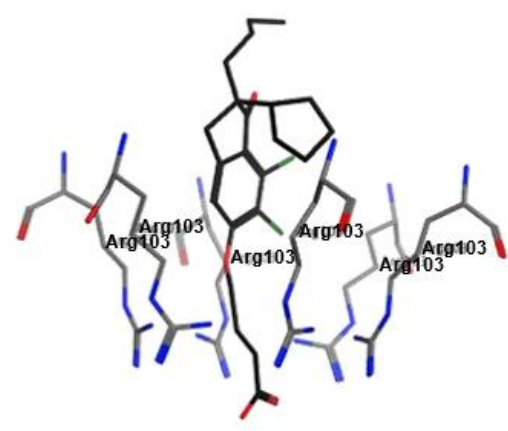

E

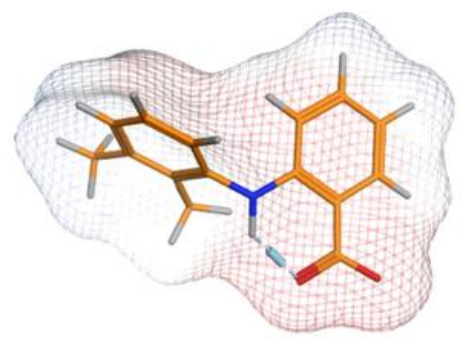

H

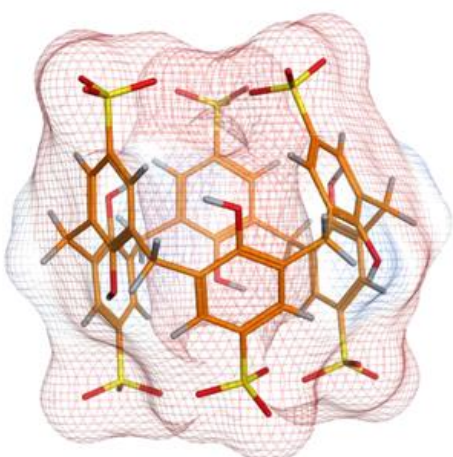

C

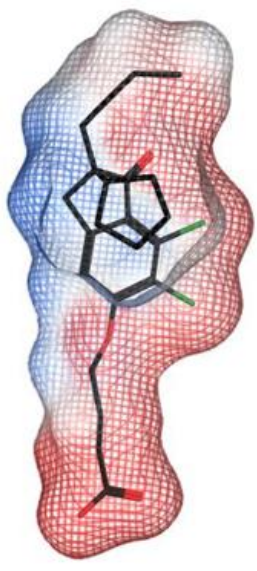

F

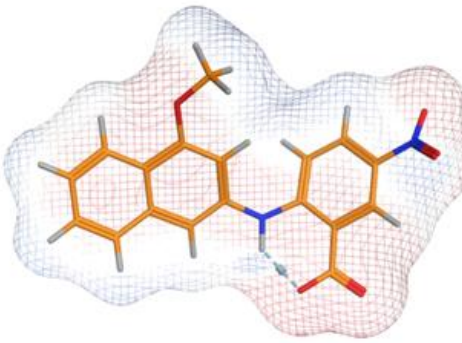

I

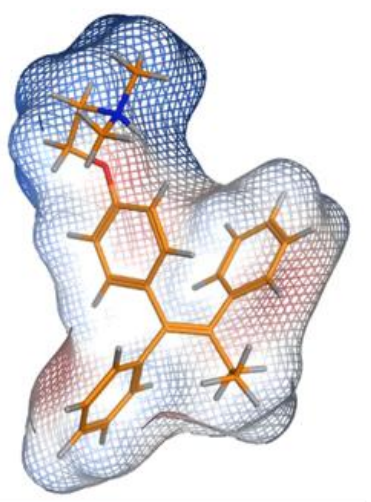


bioRxiv preprint doi: https://doi.org/10.1101/2020.06.11.146225; this version posted June 12, 2020. The copyright holder for this preprint (which was not certified by peer review) is the author/funder, who has granted bioRxiv a license to display the preprint in perpetuity. It is made available under aCC-BY 4.0 International license.

Figure S2

A

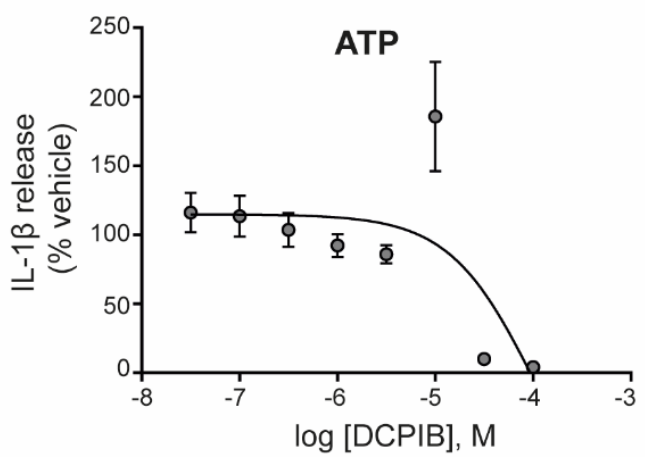

C

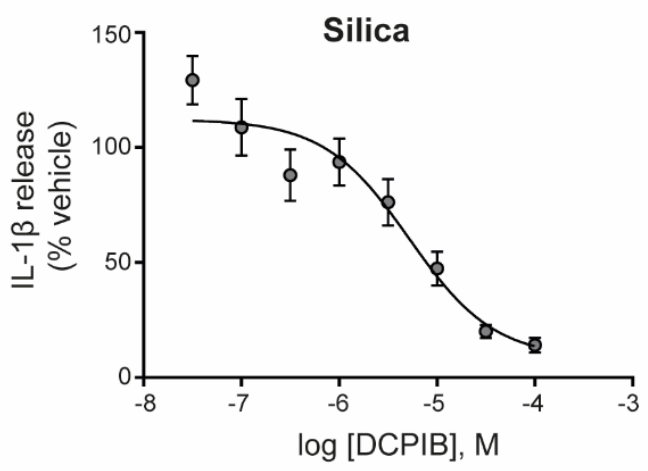

B

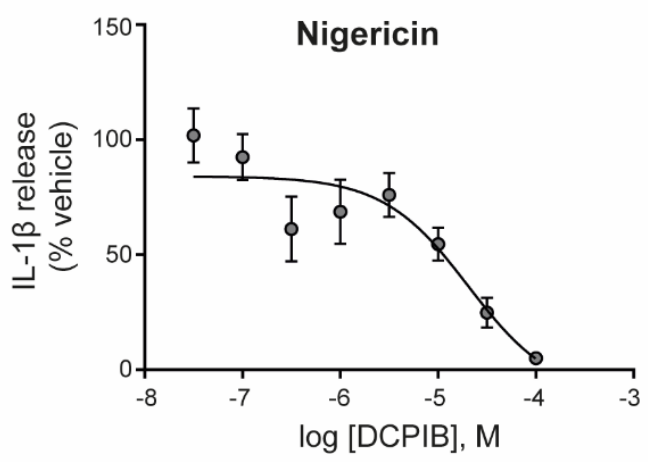


bioRxiv preprint doi: https://doi.org/10.1101/2020.06.11.146225; this version posted June 12, 2020. The copyright holder for this preprint (which was not certified by peer review) is the author/funder, who has granted bioRxiv a license to display the preprint in perpetuity. It is made available under aCC-BY 4.0 International license.

\section{Figure S3}

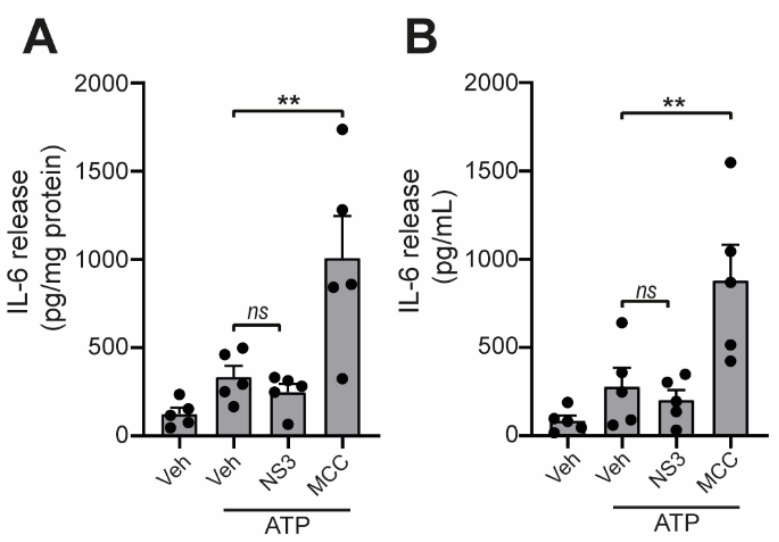

C

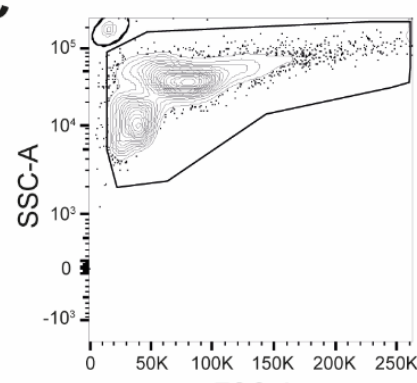

FSC-A
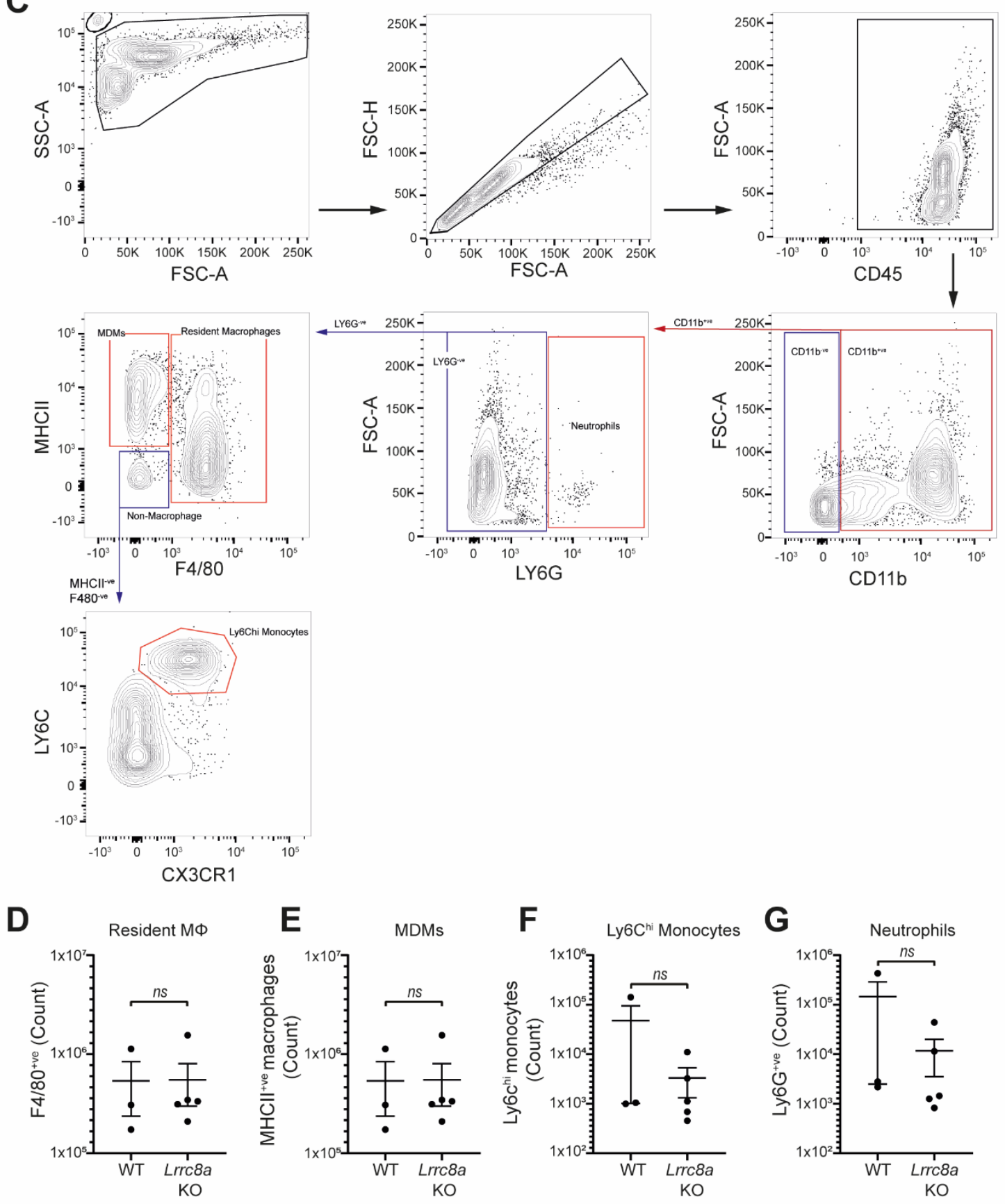